\title{
Fruit Waste Valorization for Biodegradable Biocomposite Applications: A Review
}

\begin{abstract}
Alison C. Gowman, ${ }^{\mathrm{a}, \mathrm{b}}$ Maisyn C. Picard, ${ }^{\mathrm{a}, \mathrm{b}}$ Loong-Tak Lim,,${ }^{\mathrm{c}}$ Manjusri Misra,,${ }^{\mathrm{a}, \mathrm{b}, *}$ and Amar K. Mohanty ${ }^{\mathrm{a}, \mathrm{b}, *}$

Currently, food waste is a major concern for companies, governments, and consumers. One of the largest sources of food waste occurs during industrial processing, where substantial by-products are generated. Fruit processing creates a lot of these by-products, from undesirable or "ugly fruit," to the skins, seeds, and fleshy parts of the fruits. These byproducts compose up to $30 \%$ of the initial mass of fruit processed. Millions of tons of fruit wastes are generated globally from spoilage and industrial by-products, so it is essential to find alternative uses for fruit wastes to increase their value. This goal can be accomplished by processing fruit waste into fillers and incorporating them into polymeric materials. This review summarizes recent developments in technologies to incorporate fruit wastes from sources such as grape, apple, olive, banana, coconut, pineapple, and others into polymer matrices to create green composites or films. Various surface treatments of biofillers/fibers are also discussed; these treatments increase the adhesion and applicability of the fillers with various bioplastics. Lastly, a comprehensive review of sustainable and biodegradable biocomposites is presented.
\end{abstract}

Keywords: Fruit waste; Biodegradable; Biobased plastics; Biocomposites

Contact information: a: School of Engineering, Thornbrough Building, University of Guelph, Guelph, NIG 2WI, ON, Canada; b: Bioproducts Discovery and Development Centre, Department of Plant Agriculture, Crop Science Building, University of Guelph, Guelph, N1G 2W1, ON, Canada; c: Department of Food Science, University of Guelph, Guelph, NIG 2Wl, ON, Canada;

*Corresponding authors: mmisra@uoguelph.ca; mohanty@uoguelph.ca

\section{INTRODUCTION}

One of the biggest challenges facing the world today is to produce enough food to feed the rapidly growing population. Despite efforts to produce enough food, much of it is wasted before it even reaches the consumers. According to the Food and Agriculture Organization (FAO) of the United Nations, approximately 1.3 billion tonnes of food is lost every year (Gustavsson et al. 2011). Fruit and vegetable losses in industrialized nations can exceed 32\% before reaching the point of sale (Gustavsson et al. 2011). A prominent solution to reduce food loss is to find alternative uses for products that are rejected by consumers or leftovers from food processing (ASTM D6400-04 2004). Research relating to food waste has been ongoing since the 1990s (Kroyer 1995). To assess the feasibility and prepare to utilize these by-products in industry, it is essential to identify, quantify, characterize, and analyze the by-products of choice (Rosentrater 2004). Full utilization of the by-products can only be realized when the materials' information is available.

One way to increase the use of food waste is to process it into filler and then 
incorporate it into a polymer matrix to provide strength and decrease the amount of polymer required in the composite. A further benefit to this approach is the reduction in material cost, as the more expensive polymer is replaced with low-cost filler. By combining different fruit waste fillers with a polymer, composite systems of unique properties can be tailored for specific applications. Common properties of interest include strength, toughness, and thermal stability, among others. These composites can be classified as biocomposites because they contain a biologically derived resource, i.e., the natural filler. They can be considered biodegradable if a biodegradable polymer matrix is used. In this article the term "biocomposite" will be used when both the polymer matrix and the filler particles both come from plant sources. Materials with a petrochemicalbased matrix and any kind of reinforcement, including plant-based, will just be called "composites".

"Biodegradability" is an all-encompassing term used to describe a material's ability to break down. However, a subsection within biodegradability is compostability. Compostable materials have the ability to be degraded into benign substances under certain conditions, as defined within internationally recognized standards. Factors that affect the degradability of a sample include its size, composition, and thickness, among other characteristics (ASTM D6400-04 2004). Biodegradable or compostable plastics have less environmental impact compared to non-biodegradable or non-compostable plastics because they do not place such a heavy burden on the environment. The biodegradable, compostable plastics contribute to a circular economy in which the products at the end of their life return to the soil and new starting material begins again. There is an increasing demand for these types of products, as consumers are becoming more aware of the impact of non-biodegradable plastics on the environment. Compostable alternatives can potentially alleviate disposal concerns and help create sustainable, environmentally friendly products.

This work is instrumental in providing information to both consumers and industry on the availability of sustainable polymers and composites. The cost benefits associated with the use of natural fillers and sustainability are among the many benefits to using these materials. This work discusses the availability of fruit waste materials around the world. Often, these materials can be obtained at little to no cost, as the natural fillers generated from fruit waste have limited purpose to date. The circular economy, as discussed in this work, focuses on the regeneration of value-added products from previously used materials (Ellen MacArthur Foundation 2017). A circular approach is far more sustainable in the long run, as compared to the linear practices many companies follow today, which require resources to make products and dispose of products at the end of life. Thus, the use of biocomposites is extremely important going forward, especially in single-use plastic applications (Ellen MacArthur Foundation 2017).

Biopolymers can be classified into different categories, depending on how they are produced, whether or not they are biodegradable, and their structures. There are currently many different types of biopolymers available on the market. The major considerations for classification of biopolymers are the source of the starting material and its biodegradability. Recently there has been research on the combination of petroleumbased or biobased polymers with natural fillers or fibers, which may or may not be biodegradable. It is important to clarify that although a material may be biologically based, it might not be biodegradable. This paper intends to focus on biodegradable polymers, regardless of their starting material.

There have been some studies examining composites derived from natural fillers 
or fibers and non-biodegradable polymers, which are more sustainable than entirely petro-based materials. These studies feature the combination of fruit waste with petroleum-based polymers such as high density polyethylene (HDPE) (Banat and Fares 2015; Satapathy and Kothapalli 2018), polypropylene (PP) (Naghmouchi et al. 2015; Essabir et al. 2016), and epoxy and polyester resins (Durowaye et al. 2014; Ruggiero et al. 2016).

Research by Banat and Fares (2015) combined olive pomace and HDPE to make composites. The addition of a coupling agent improved the interfacial adhesion such that the olive pomace could act as a reinforcing material. Recycled HDPE (RHDPE) has been used in combination with banana fibers, a compatibilizer, and additional filler to generate composites. Banana fiber was a renewable, cost-effective, and non-abrasive filler used to increase the sustainability of an engineering thermoplastic (Satapathy and Kothapalli 2018). Other petro-based thermoplastics have been used as a matrix material. Polypropylene, for example, was combined with olive stone pomace by Naghmouchi et al. (2015) to develop composites. The researchers added maleic anhydride-grafted PP to improve the interfacial adhesion and further improve the mechanical performance (Naghmouchi et al. 2015). Coir fiber and shell particles were combined with PP by Essabir et al. (2016) to generate composites. Interestingly, the tensile modulus improved with the combination of the fiber and coir particles. The sustainability of the composites was improved, supporting their use with biobased and biodegradable polymers. Furthermore, the addition of coupling agents improved the performance of the fabricated materials (Essabir et al. 2016).

Unsaturated polyester resins (as a matrix material), a catalyst and an accelerator were combined with coconut shell fibers and palm fruit to generate composites. The optimal filler contents for coconut shell and palm fruit filler were $10 \mathrm{wt} \%$ and $20 \mathrm{wt} \%$, respectively (Durowaye et al. 2014). Date stones, also known as the seeds, were used as the filler in resins to make composites via casting methods (Ruggiero et al. 2016). The addition of a low-cost filler helps to generate renewable materials for a more sustainable future. The reduction in cost, compared to neat polymer, is also an incentive for use in industrial production of composites. Aht-Ong and Charoenkongthum (2002) combined low-density polyethylene (LDPE), banana starch, and ethylene vinyl acetate copolymer (EVA). The EVA acted as a compatibilizing agent to improve the interactions between the filler and the matrix. These films functioned well, but there could be improvement with the sustainable content overall.

There has been limited research performed with tomato pomace and biobased or biodegradable plastics to date. However, post-harvest tomatoes have been used in combination with ethylene vinyl alcohol (EVOH) to make films (Nisticò et al. 2017). The films reduced the cost and overall consumption of petro-based plastic materials because tomato waste was able to act effectively as an additive. The addition of the natural filler improved the overall sustainability of the materials (Nisticò et al. 2017).

There is a popular misconception that the addition of natural fibers changes the biodegradability of non-biodegradable polymers when used to make composites. However, this is not the case. The addition of natural fillers or fibers increases the sustainability of the samples by increasing the renewable content but does not change the inherent nature of the continuous phase. If the continuous phase is not biodegradable, the addition of natural fibers will not change its biodegradability. Therefore, it is important to note that not all composites containing plant-based material are biodegradable, since their biodegradability is most determined by the matrix material. 
Overall, this paper provides a comprehensive review of biodegradable composites containing natural fillers, highlighting the feasibility and importance of natural, renewable, and sustainable materials. Going forward, producers of plastics (especially single-use plastics) should keep in mind the end-of-life plan during product development to ensure a cleaner future for the environment. This ideology is discussed extensively by the Ellen MacArthur Foundation, calling it the "circular economy approach." The circular economy approach, as shown in Fig. 1, illustrates how materials can be reused and recycled. In this work, the valorization of fruit waste re-uses an existing by-product to generate value-added and novel products (Ellen MacArthur Foundation 2017).

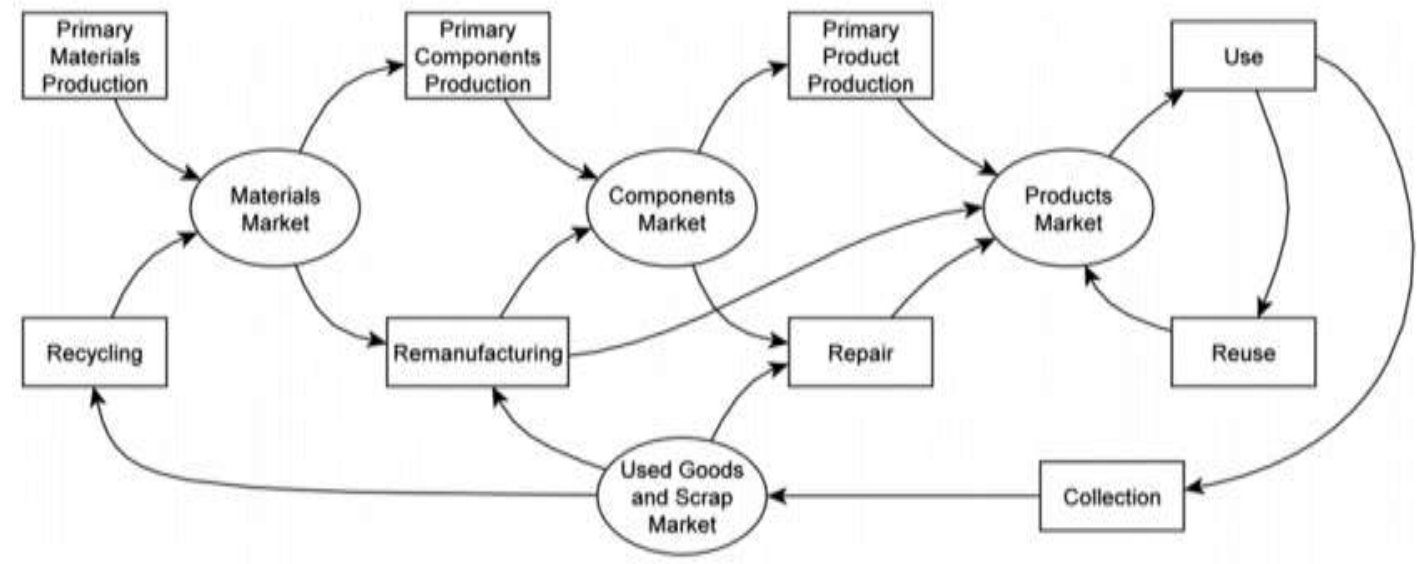

Fig. 1. A circular economy approach to sustainable product development. Reprinted with permission from John Wiley \& Sons: Journal of Industrial Ecology, (Zink and Geyer 2017), Copyright 2017, License Number: 4561921510933.

\section{BIODEGRADABLE POLYMERS}

Biodegradable polymers can be degraded into water and carbon dioxide in the presence of microorganisms. Their degradation is strongly dependent on their surrounding environmental conditions, such as temperature and humidity (Mohanty et al. 2005). A polymer is deemed biodegradable when the polymer degrades during its application or soon after its application (Göpferich 1996). When a significant loss in properties occurs due to thermal, mechanical, or chemical degradation, or from photoexposure, a polymer can be deemed degradable (Göpferich 1996).

Degradable materials can be further specified as compostable. According to standards such as ASTM D5988-18 (2018) or ASTM D5338-15 (2015), a compostable plastic is a plastic that yields carbon dioxide, water, inorganic compounds, and biomass at a rate comparable to other known compostable materials and leaves no visible, distinguishable, or toxic residue. After 12 weeks there should be $10 \%$ of the original dry weight or less remaining when sieved on a 2 mm sieve (ASTM D5338-15 2015; ASTM D5988-18 2018).

\section{Biobased or Renewable Resource-based Biodegradable Polymers}

Biobased or renewable resource-based biodegradable polymers are polymers produced from renewable resources. Some renewable resources used to fabricate 
polymers are plant-based, such as sugarcane or corn. Other renewable sources include bacterial fermentation of sugars. The most common biobased and biodegradable polymers include polylactic acid (PLA), polyhydroxyalkanoates (PHAs), and starch.

\section{Polylactic acid (PLA)}

Polylactic acid is a widely used, fully biobased polymer made from cassava, sugarcane, or corn. Polylactic acid is widely used due to its biodegradability, good mechanical properties, and comparatively low cost. There are different types of PLA, depending on the orientation of its monomer units. Lactic acid has two chiral carbons, which allow it to have different stereoisomers, namely L-lactide, D-lactide, and L-Dlactide. The properties of PLA are highly dependent on the stereochemical composition. When lactic acid (the precursor to PLA) is derived from biological sources, the majority of it is L-lactic acid, with a small amount being D-lactic acid. Therefore, PLA produced from biological sources is mainly composed of poly(L-lactide) (Garlotta 2001).

Polylactic acid is also a versatile material which can be processed in many ways, such as injection molding, thermoforming, blow molding, extrusion blown film, foaming, sheet extrusion, and film extrusion (Auras et al. 2010). The main disadvantages associated with PLA are its poor impact strength and low heat distortion temperature. Due to these disadvantages, many studies have been performed to overcome these properties by melt blending PLA with other polymers or additives to improve its properties (Mekonnen et al. 2013; Nagarajan et al. 2016).

\section{Polyhydroxyalkanoates (PHAs)}

Polyhydroxyalkanoates are polyesters created from bacterial fermentation. They can be synthesized by different strains of bacteria with each synthesized material exhibiting unique properties. The composition of the derived PHA polymer depends on the growth medium used (Reddy et al. 2003).

Polyhydroxyalkanoates can be classified into different groups, depending on their carbon numbers. Short chain length (SCL) PHAs have monomers with 2 carbon atoms to 5 carbon atoms, whereas medium chain length (MCL) polymers have monomers with 6 carbon atoms to 14 carbon atoms (Park et al. 2012). While there are many types of PHAs that can be synthesized, most are not commercially available. The most common industrially produced PHAs can be listed as medium chain length PHA (MCL PHA), polyhydroxybutyrate (PHB), and poly(hydroxybutyrate-co-valerate) (PHBV) (Chen 2009).

Polyhydroxybutyrate has poor melt processability and thermal stability, crystallizes slowly, and is brittle (Muthuraj et al. 2018). The properties of PHB can be modified and improved by copolymerization with hydroxyvalerate (HV), resulting in a product called PHBV, which, with its high HV content, has better ductility and toughness compared to PHB (Avella et al. 2000). Although PHBV is biocompatible, it has poor thermal stability and is expensive, difficult to process, and brittle. The crystallinity and polymer type of PHAs determine their degradation rate. The main uses for PHAs are plastic shopping bags, medical applications (such as tissue scaffolding and bone healing), agricultural films, fishing nets, and cosmetic packaging (Philip et al. 2007). Other researchers have reviewed many different articles on the preparation, properties, potential applications, and future development of PHAs (Avella et al. 2000; Philip et al. 2007). 


\section{Starch}

Starch is a carbohydrate polymer that consists of many glucose units joined together by glycosidic bonds. It contains approximately $20 \%$ to $25 \%$ linear amylose and $75 \%$ to $80 \%$ helical/branched amylopectin by weight. It is found in many plants, such as potatoes, cereal grains, rice, maize, and cassava, among others. The characteristics of starches can differ depending on the amylose-to-amylopectin ratio, crystallinity, and glass transition temperature $\left(T_{\mathrm{g}}\right)$. The properties associated with starch, such as the high $T_{\mathrm{g}}$ (approximately $240{ }^{\circ} \mathrm{C}$ ), strong inter- and intra-molecular hydrogen bonding, water sensitivity, and poor flowability of the starch granules, can limit processability and therefore reduce the amount of applications starch can be used in (Mekonnen et al. 2013).

These challenges can be overcome by the incorporation of plasticizers, blending with polymers, chemical modification, or a combination of these methods (Mekonnen et al. 2013). Starch can be plasticized with water, glycerol, glycol, sorbitol, fructose, mannose, fatty acids, etc. (Rosa et al. 2009; Luchese et al. 2018). Chemical modifications such as hydroxylation, acylation, oxidation, and acetylation have been reported to improve its processability and mechanical properties (Zamudio-Flores et al. 2010; Mekonnen et al. 2013). Although chemical modification is an effective way to modify starch, it can produce harmful by-products and is normally quite expensive. Therefore, plasticization is thought to be the best method to enhance the properties of starch.

\section{Biobased and Organic Additives to Biodegradable Polymers}

Biobased additives are derived from natural sources and are added to composites or films to improve their properties or material stability. Most often, the additives are used as plasticizers or binding agents.

\section{Glycerol}

Glycerol, also known as 1,2,3-propanetriol, is a simple polyol containing three hydroxyl groups. Animals, plants, and microorganisms naturally synthesize glycerol. Industrially, it can be produced from biobased or petro-based sources (Pagliaro et al. 2007). Here, the synthesis of biobased glycerol is the focus. Biobased glycerol can be obtained from saponification or from the hydrolysis of fats and oils. Saponification functions by creating soap from the fermentation of sugars to glycerol by microorganisms. It can also be obtained from transesterification of fats and oils in biodiesel production as a coproduct (Pagliaro et al. 2007). Glycerol is often used as a plasticizing agent when combined with other materials such as starch (Park et al. 2009; Deng and Zhao 2011).

\section{Sorbitol}

Sorbitol is a natural alcohol found in fruits and is a common plasticizer in biobased/edible films to aid extensibility and permeability (Shaw et al. 2002). It is the high molecular weight molecules that maintain a solid state a room temperature. When combined with film materials, it can impinge on the molecular interactions between molecules of the polymer, thereby reducing the brittleness and increasing flexibility of the films (Shaw et al. 2002). More specifically, sorbitol acts to increase the intermolecular spacing between molecules by reducing the hydrogen bonding between internal structures (McHugh and Krochta 1994). 


\section{Hexamethylenetetramine}

Hexamethylenetetramine (HMTA) is a water-soluble organic compound made via a condensation reaction of organic compounds (Blažzević et al.1979). It is added to films such as polyvinyl alcohol (PVOH) to act as a cross-linking agent (Ooi et al. 2011; Zhong et al. 2011). Hexamethylenetetramine has also been used in other applications such as medicine.

\section{Cellulose}

Cellulose is one of the world's most abundant natural polymers. It consists of linear chain consisting of anhydro-glucose monomers attached through 1-4 $\beta$-linkages (Nazir et al. 2013). In some cases, cellulose can be extracted from fruits such as durian (Penjumras et al. 2016) and oil palm empty fruit bunches (Nazir et al. 2013). Cellulose can be used in many ways in composites applications, such as being used as a reinforcing agent in powder form, nanofibers, and nanocrystals (Penjumras et al. 2016; Gouw et al. 2017).

\section{Petroleum-based Biodegradable Polymers}

Some polymers that can be created either entirely or partially from petroleumbased feedstocks can also be biodegradable. Examples of these polymers are poly(butylene adipate-co-terephthalate) (PBAT), PVOH, and poly(butylene succinate) (PBS).

\section{Poly(butylene adipate-co-terephthalate)}

Poly(butylene adipate-co-terephthalate) is synthesized from 1,4-butanediol, adipic acid, and terephthalic acid via polycondensation reactions. It has good mechanical properties, which are comparable to the properties of LDPE, though its barrier properties are slightly different from those of LDPE (Costa et al. 2015). Poly(butylene adipate-coterephthalate) can be processed with normal polymer processing techniques, including mixing, extrusion, and injection molding. The downside to utilizing PBAT is its relatively low degradation temperature $\left(140{ }^{\circ} \mathrm{C}\right.$ to $\left.230{ }^{\circ} \mathrm{C}\right)$, which can cause it to degrade during processing (Costa et al. 2015).

\section{Polyvinyl alcohol}

PVOH is synthesized from poly(vinyl acetate) by full or partial hydroxylation. The amount of hydroxylation determines the characteristics of the material, such as its chemical properties, physical characteristics, and mechanical properties (Baker et al. 2012). PVOH is often used in medical applications as contact lenses, artificial cartilage, and meniscuses due to its biocompatibility, chemical resistance, high water solubility, and adsorption characteristics (Baker et al. 2012).

\section{Poly(butylene succinate)}

Poly(butylene succinate) is a biodegradable polymer that can be synthesized entirely from petroleum or be partially biobased, utilizing biobased succinic acid. It is created from 1,4-butanediol and succinic acid. Its properties are similar to PP and polyethylene (PE) (Fujimaki 1998). Poly(butylene succinate) can be processed easily by injection molding, sheet extrusion, thermoforming, blow molding, and compression molding. 


\section{Polycaprolactone}

Polycaprolactone (PCL) is a semi-crystalline biodegradable polymer with a low melting temperature of $60{ }^{\circ} \mathrm{C}$ and a glass transition temperature of $-60{ }^{\circ} \mathrm{C}$. It is synthesized from $\varepsilon$-caprolactone via a ring-opening polymerization reaction. The degradation of the polymer is based on hydrolysis of the ester linkages. It has gained increasing interest in biomedical applications such as implants and drug delivery systems (McKeen 2012), as well as in sustainable packaging (Ahmad et al. 2018).

\section{BIOFILLERS AND FIBERS}

Biobased fillers and fibers have been widely used since the 1940s (Mohanty et al. 2000). Biofillers and fibers are advantageous because of their low cost, light weight, and abundance. Incorporating them into a composite increases the amount of biocontent in the composite, which in turn creates a more environmentally friendly product. The use of biofillers also reduces carbon footprints and improves energy security (Mohanty et al. 2018). Biofillers and fibers have other advantages such as reduced tool wear, good thermal properties, reduced worker respiratory irritation, and biodegradability (Mohanty et al. 2000). The downside associated with fillers or fibers is their hydrophilicity, which decreases compatibility with typical polymer matrices that are relatively hydrophobic. The other disadvantage is the low processing temperature to prevent degradation. On average, the thermal degradation temperature for fillers is approximately $180{ }^{\circ} \mathrm{C}$, which limits their use in engineering thermoplastics. Some of these challenges are overcome by modifications, as discussed later.

\section{Fillers}

Biofillers reinforce the strength and stiffness of a material. Their properties depend on their source, including what part of the plant they are taken from, the quality of the plant, and its age, among other factors. In this paper, all the fillers discussed are from fruits.

Fillers are typically composed of cellulose, hemicellulose, lignin, and protein because they are not limited to only the fibrous component of plants. Variations in growing season and preparation of the filler can influence its properties, along with the components included in the filler.

Natural fillers considered in this review include apple, banana, acai berry, blueberry, cranberry, coconut, grape, durian, rambutan, olive, mango, pineapple, and date (Table 1). In many cases, the waste is a combination of the skin, flesh components, and seed components. However, some stem materials and leaves would be present and could be processed from these biomass sources. 
Table 1. Fruits Used as Filler or Fiber in Composites and Films

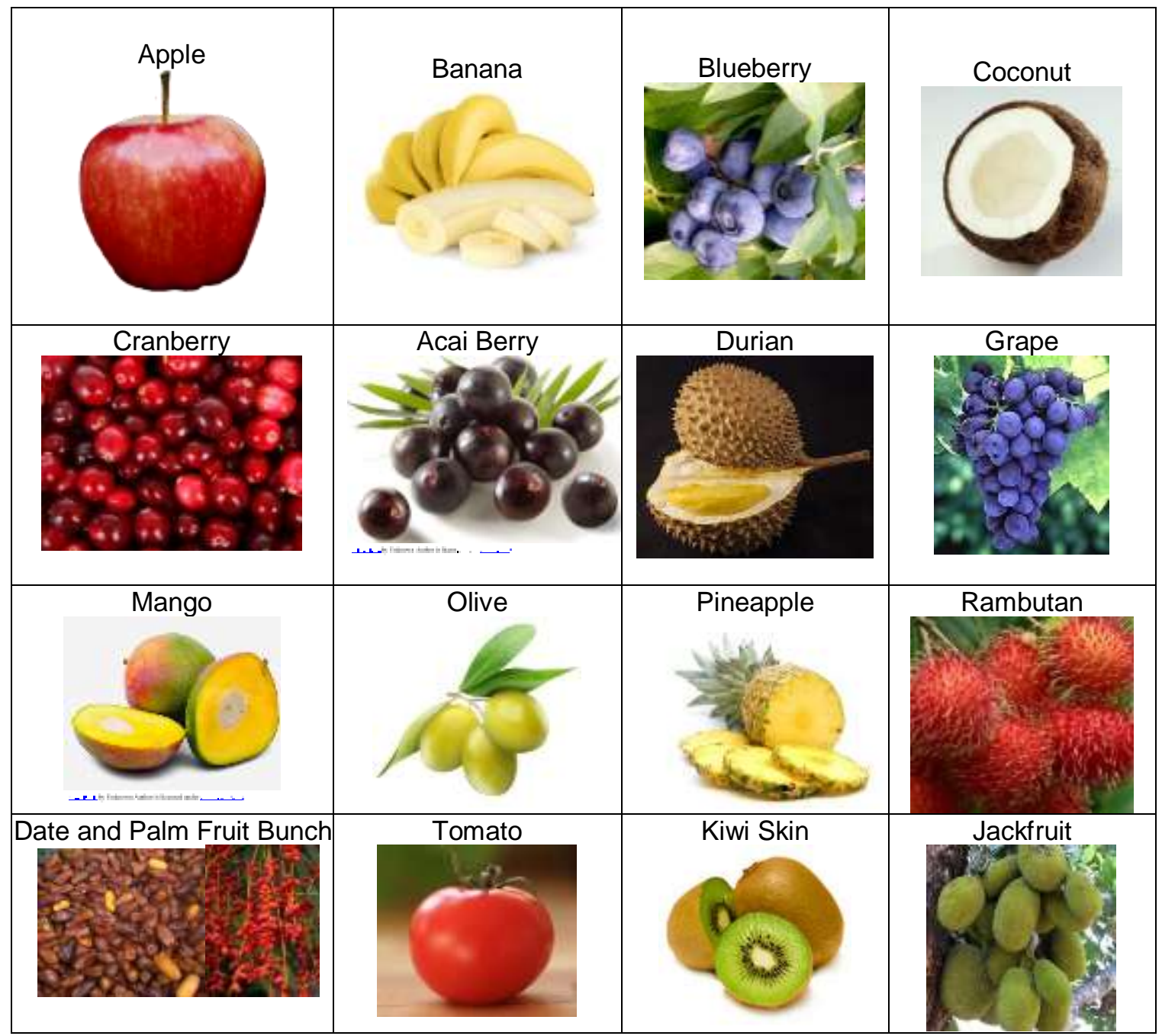

Quantity of Fillers

The global production of the various fruits is shown in Table 2. The average waste generated from whole fruits is approximately 30\% (Vendruscolo et al. 2008). Wastes generated from apples, grapes, and olives are commonly referred to as "pomace" or "marc," as they are pressed to extract the liquid components for applications such as making juice or wine. 
Table 2. Global Fruit Production in Weight of Whole Fruit

\begin{tabular}{|c|c|c|c|}
\hline Fruit & Global Production & Waste (\%) & Total Waste \\
\hline Apple & $\begin{array}{l}\text { 74.2 million tonnes (2018) } \\
(\text { USDA 2018) }\end{array}$ & $\begin{array}{c}20 \\
\text { (Gouw et al. 2017) }\end{array}$ & $\begin{array}{l}14.8 \text { million } \\
\text { tonnes }\end{array}$ \\
\hline Grape & $\begin{array}{l}23.4 \text { million tonnes (2018) } \\
(\text { USDA 2018) }\end{array}$ & $\begin{array}{c}25 \\
\text { (Dwyer et al. 2014) }\end{array}$ & $\begin{array}{l}5.85 \text { million } \\
\text { tonnes }\end{array}$ \\
\hline Banana & $\begin{array}{l}\sim 114 \text { million tonnes (2017) } \\
(\text { FAO 2019a) }\end{array}$ & 30 & $\begin{array}{l}34.2 \text { million } \\
\text { tonnes }\end{array}$ \\
\hline Pineapple & $\begin{array}{l}\text { 25.8 million tonnes (2017) } \\
\text { (Altendorf 2019) }\end{array}$ & 30 & $\begin{array}{l}7.74 \text { million } \\
\text { tonnes }\end{array}$ \\
\hline Mango & $\begin{array}{l}\text { 48.3 million tonnes (2017) } \\
\text { (Altendorf 2019) }\end{array}$ & 30 & $\begin{array}{l}14.49 \text { million } \\
\text { tonnes }\end{array}$ \\
\hline Blueberry & $\begin{array}{l}0.59 \text { million tonnes (2017) } \\
(\text { FAO 2019b) }\end{array}$ & 30 & $\begin{array}{l}177 \text { thousand } \\
\text { tonnes }\end{array}$ \\
\hline Coconut & $\begin{array}{l}\sim 60.8 \text { million tonnes }(2017) \\
\text { (FAO 2019b) }\end{array}$ & 30 & $\begin{array}{l}18.24 \text { million } \\
\text { tonnes }\end{array}$ \\
\hline Coir & $\begin{array}{l}1.23 \text { million tonnes }(2017) \\
(\text { FAO 2019b) }\end{array}$ & 30 & $\begin{array}{l}369 \text { thousand } \\
\text { tonnes }\end{array}$ \\
\hline Date & $\begin{array}{l}8.17 \text { million tonnes }(2017) \\
(\text { FAO 2019b) }\end{array}$ & 30 & $\begin{array}{l}2.45 \text { million } \\
\text { tonnes }\end{array}$ \\
\hline Kiwi & $\begin{array}{l}\sim 4.04 \text { million tonnes }(2017) \\
(\text { FAO 2019b) }\end{array}$ & 30 & $\begin{array}{l}1.21 \text { million } \\
\text { tonnes }\end{array}$ \\
\hline Olive & $\begin{array}{l}\text { 20.9 million tonnes (2017) } \\
\text { (FAO 2019b) }\end{array}$ & $\begin{array}{c}35 \\
\text { (Banat and Fares 2015) }\end{array}$ & $\begin{array}{l}7.32 \text { million } \\
\text { tonnes }\end{array}$ \\
\hline Cranberry & $\begin{array}{l}0.63 \text { million tonnes (2017) } \\
(\mathrm{FAO} 2019 \mathrm{~b})\end{array}$ & 1 & $\begin{array}{c}189 \text { thousand } \\
\text { tonnes }\end{array}$ \\
\hline Durian & $\begin{array}{c}\sim 3800 \text { tonnes }(2016) \\
(\text { Lee et al. 2018) }\end{array}$ & $\begin{array}{c}60 \\
\text { (Lee et al. 2018) }\end{array}$ & 2280 tonnes \\
\hline
\end{tabular}

The pomace materials are usually abundantly available but serve very little purpose. In fact, Gouw et al. (2017) estimated that only $20 \%$ of apple pomace generated is used for a value-added purpose, whereas the rest remains animal feedstock or is left for compost. Based on the global production of fruit, there are substantial amounts of biomass waiting to be repurposed.

The total waste was calculated by multiplying the global production by the estimated weight percentage of waste, i.e., approximately $30 \%$ for fruit. Based on the estimated total wastes generated from fruit processing, there are apparently millions of tonnes of materials in need of a value-added purpose. Currently, some of the waste is used in biorefining and energy production, chemical extraction to generate useful products, or animal feedstocks. However, fruit waste that ends up in landfills or as compost does not possess any sort of added benefit but, rather, generates environmental burden. Therefore, if the biomass is instead used to produce value-added products, then the carbon is sequestered, the impact on the environment is reduced, and the overall sustainability of the materials is improved.

\section{Physicochemical composition of fillers}

As mentioned earlier, cellulose, hemicellulose, and lignin are among the major constituents of biobased fillers. Each fruit possesses a unique combination of each of these fractions (Table 3), affected by the agricultural conditions (Muensri et al. 2011). Cellulose is often located within the backbone structure of the fiber. In contrast, lignin is a polyphenolic compound of amorphous structure, located on the outside of the fiber 
(Muensri et al. 2011). The lignocellulosic materials in the natural fiber are responsible for cross-linking to the polymer matrix. More cross-linking between the filler and the matrix results in better interfacial adhesion, which enhances the filler's ability to distribute stresses throughout the matrix materials. Better interfacial adhesion often results in improved impact strength of composites (Picard et al. 2019). The lignocellulose content can also affect other properties of the composites.

Table 3. Cellulose, Hemicellulose, and Lignin Contents of Various Fruit Biomasses

\begin{tabular}{|c|c|c|c|c|}
\hline Fruit & $\begin{array}{c}\text { Cellulose } \\
(\%)\end{array}$ & $\begin{array}{c}\text { Hemicellulose } \\
(\%)\end{array}$ & $\begin{array}{c}\text { Lignin } \\
(\%)\end{array}$ & Reference \\
\hline Apple & 47.49 & 27.77 & 24.72 & Guerrero et al. (2014) \\
\hline Grape & 17.5 & 6.9 & 51.7 & Gómez-Brandón et al. (2011) \\
\hline Coconut husk & 34 & 21 & 27 & Bledzki et al. (2010) \\
\hline Pineapple leaf & 66.2 & 19.5 & 4.28 & Daud et al. (2014) \\
\hline Banana fiber & $63-64$ & 19 & 5 & Deepa et al. (2011) \\
\hline Durian & 60.45 & 13.09 & 15.45 & Aimi et al. (2014) \\
\hline Coir fiber & 32.69 & 22.56 & 42.10 & Muensri et al. (2011) \\
\hline Olive stone flour & 25 & 34 & 34.5 & Naghmouchi et al. (2015) \\
\hline Mango peel & 9.19 & 14.51 & 4.25 & Sánchez Orozco et al. (2014) \\
\hline Post-harvest tomato & 33.1 & 10.5 & 7.8 & Nisticò et al. (2017) \\
\hline Rambutan peel & 24.28 & 11.62 & 35.34 & Oliveira et al. (2016) \\
\hline $\begin{array}{c}\text { Palm oil empty fruit } \\
\text { bunch }\end{array}$ & 37.26 & 14.62 & 31.68 & Sudiyani et al. (2013) \\
\hline
\end{tabular}

Thermal stability of composites is strongly dependent on the presence of natural filler. Thermogravimetric analysis reveals that hemicellulose is the first lignocellulosic material to degrade between $150{ }^{\circ} \mathrm{C}$ and $350{ }^{\circ} \mathrm{C}$ (Yang et al. 2005). Cellulose and lignin are the next to degrade, at $275^{\circ} \mathrm{C}$ to $350{ }^{\circ} \mathrm{C}$ and $250{ }^{\circ} \mathrm{C}$ to $500{ }^{\circ} \mathrm{C}$, respectively $(\mathrm{Kim}$ et al. 2005). It can be inferred that samples with greater hemicellulose contents, relative to cellulose and lignin, would be less thermally stable and therefore be recommended for combining with plastics that have lower melting points.

\section{Fibers}

In composite applications, fibers enhance the strength and stiffness of a material. The properties of the fibers depend on their source, i.e., whether they are from the stem of the plant or the leaves of the plant, the quality of the plant, and the age of the plant. Natural fibers can be placed into different groups: leaf, bast, seed, and fruit. This review will focus on fruit leaf and fruit fibers, as they are both by-products of food processing. Natural fibers exhibit variation in length and diameter. Other factors determining the properties are size, maturity, and the processing method used for extraction of the fibers (Mohanty et al. 2000).

\section{Modification of Fibers or Filler}

Surface modification of fibers is needed for improving their performance. In composite applications, strong fiber-matrix interaction is crucial for good mechanical properties (Mohanty et al. 2018). However, natural fibers are hydrophilic, which presents a problem when they are added to a polymer matrix that is hydrophobic. Fibers also tend to have a waxy coating on their surface, which causes weak matrix bonding and poor 
surface wetting (Mohanty et al. 2001). Therefore, surface modification to reduce the hydrophilicity of the fibers can improve the matrix adhesion. Modifications such as washing, peroxide treatment, alkali treatment, bleaching, and the use of silane coupling agents have yielded fiber enhancement (Mohanty et al. 2001). Not only does surface treatment improve the interfacial adhesion, but it can also aid in filler dispersion (La Mantia and Morreale 2011).

Each of the different modification methods has advantages and disadvantages. For example, silane treatments usually result in strong enhancement of mechanical properties. For thermal stability, alkali treatments and acetylation are usually more favorable (La Mantia and Morreale 2011). However, chemical modification is costly and complex, thereby limiting its industrial relevance. Due to these limitations, the most common approach to enhancing natural filler/fiber composites is to add small amounts of compatibilizer to enhance the material properties. The compatibilizer should have both hydrophilic and hydrophobic moieties, which interact with polar groups on the filler's surfaces and polymer molecular chains, respectively. Although the addition of compatibilizer is common, it is not the focus of this review.

\section{Washing}

Washing of fibers is a routine step when modifying fibers. Washing fibers in water alone or with water and a mild detergent removes dust or any other impurities that could be present. Fibers are usually also washed after chemical modification to remove any residual chemicals. Washing has also been used to remove excess free sugars in some biomass sources to improve the thermal stability at polymer processing temperatures.

\section{Bleaching}

Bleaching of fibers is done to remove colour and/or to modify the surface properties. In lignocellulosic fibers, the colour of the fibers can be associated with lignin (Razak et al. 2014). Bleaching also enhances mechanical properties, as it can increase the surface roughness of the fibers, resulting in stronger fiber-matrix adhesion (Razak et al. 2014).

\section{Peroxide treatment}

Peroxides are molecules with an O-O group. Peroxides can decompose easily, forming free radicals in the form of $\mathrm{RO}^{\prime}$, which then react with the hydrogen groups on the surface of the fibers. For example, the hydrogen on the cellulose $(\mathrm{Cell}-\mathrm{H})$ interacts with RO', which in turn can react with the polymer as shown in Eq. 1 (Joseph et al. 1996):

$$
\begin{aligned}
& \mathrm{RO} \cdot+\text { “Cell }-\mathrm{H} " \rightarrow \mathrm{ROH}+\text { Cellulose } \\
& \text { Polymer }+ \text { Cellulose } \rightarrow \text { Polymer }- \text { Cellulose }
\end{aligned}
$$

Peroxide treatment can remove surface impurities, hemicellulose, and lignin and can also increase the surface roughness of the fibers, increasing the fiber-matrix interaction (Razak et al. 2014). For peroxide treatments, fillers/fibers are added to a peroxide solution and left to soak. The fillers/fibers are washed to remove any residual peroxide and then dried. 


\section{Alkali treatment}

Alkali treatment, also called "mercerization" if the concentration is high enough, is a low-cost and effective method for surface modification of fibers. The reaction between sodium hydroxide $(\mathrm{NaOH})$ and cellulose fiber $(\mathrm{Cell}-\mathrm{OH})$ is shown in Eq. 2 (Mohanty et al. 2001):

$$
\text { "Cell }-\mathrm{OH}^{\circ}+\mathrm{NaOH} \rightarrow \text { "Cell }-\mathrm{O}^{-} \mathrm{Na}^{+} "+\mathrm{H}_{2} \mathrm{O}+\text { surface impurities }
$$

This treatment is effective in removing lignin, wax, and oil that cover the external surface of the fiber, depolymerizing the cellulose structure, and exposing crystallites of short length (Mohanty et al. 2001). It also increases the surface roughness by disrupting the hydrogen bonding in the network structure (Li et al. 2007). During alkali treatment, fibers are immersed in $\mathrm{NaOH}$ solution. The fibers are then removed and dried. The $\mathrm{NaOH}$ concentration and soaking time need to be optimized because high $\mathrm{NaOH}$ concentration or extended soak duration can result in undesired fiber characteristics (Li et al. 2007). Typically, low concentrations of $\mathrm{NaOH}$ (approximately $5 \%$ or less) are incorporated with water in a bath. The filler/fibers are then soaked for a short duration, from $30 \mathrm{~min}$ to a few hours. The filler/fibers are then washed to remove the $\mathrm{NaOH}$ and dried to remove moisture.

\section{Acetylation treatment}

Acetylation is a type of esterification method that introduces an acetyl group into a compound. The acetic anhydride addition to the lignocellulosic components of the biofiller/fiber causes an esterification reaction with the hydroxyl groups in the cell walls of the biofiller/biofiber (Rowell 2004). Acetic acid is formed as a by-product of the reaction. This reaction is shown in Eq. 3 (Rowell 2004):

$$
\begin{aligned}
& \text { "Cell wall }-\mathrm{OH} "+{ }^{\circ} \mathrm{CH}_{3} \mathrm{C}(=\mathrm{O})-\mathrm{O}-\mathrm{C}(=\mathrm{O})-\mathrm{CH}_{3} " \\
& \text { "Cell wall }-\mathrm{O}-\mathrm{C}(=\mathrm{O})-\mathrm{CH}_{3} "+{ }^{\circ} \mathrm{CH}_{3} \mathrm{C}(=\mathrm{O})-\mathrm{OH}^{\prime} "
\end{aligned}
$$

For acetylation, biofillers/fibers are soaked in water and then filtered and placed in an acetylation solution. The temperature, duration, and exact chemicals used can vary, but the fillers/fibers are typically washed and dried after this process (Bledzki et al. 2008)

\section{Silane treatment}

Silane is an inorganic compound with the chemical formula $\mathrm{SiH}_{4}$. Silane may reduce the amount of cellulose hydroxyl groups on the surface of the filler and reduces the fiber-matrix interaction ( $\mathrm{Li}$ et al. 2007). Silane reacts with water and forms silanol and alcohol. The silanol then reacts with the $\mathrm{OH}$ groups on the fiber, resulting in stable covalent bonds on the surface of the fiber (Agrawal et al. 2000). The proposed reaction is shown in Eqs. 4 and 5 (Agrawal et al. 2000):

$$
\begin{aligned}
& \mathrm{CH}_{2} \mathrm{CHSi}\left(\mathrm{OC}_{2} \mathrm{H}_{5}\right)_{3} \rightarrow \mathrm{CH}_{2} \mathrm{CHSi}(\mathrm{OH})_{3}+3 \mathrm{C}_{2} \mathrm{H}_{5} \mathrm{OH} \\
& \mathrm{CH}_{2} \mathrm{CHSi}(\mathrm{OH})_{3}+\text { "Fiber }-\mathrm{OH} \text { " }+\mathrm{H}_{2} \mathrm{O} \rightarrow{ }^{\prime \prime} \mathrm{CH}_{2} \mathrm{CHSi}(\mathrm{OH})_{2} \mathrm{O}-\text { Fiber" }
\end{aligned}
$$

The swelling of the fiber is prevented because the silane creates a crosslinked network of covalent bonds between the fiber and matrix ( $\mathrm{Li}$ et al. 2007). There are many different silanes used, along with different concentrations, such as $1 \mathrm{M} \mathrm{NaOH}$ for $1 \mathrm{~h}$ at room temperature (Jandas et al. 2011). For example, long-chain alklyl methoxysilanes can be used to prepare hydrophobic plant-based fibers (Sgriccia et al. 2008). For silane treatments, the fillers/fibers are soaked in a mixture containing a small amount of silane, 
with a mixture of water and ethanol or a solvent mixture such as toluene/ethanol/acetone (Shih et al. 2014; Hemsri et al. 2012). After soaking for a specific duration, the fibers are washed and dried. The specific conditions depend on the silane used and the desired properties.

\section{Plasma treatment}

Plasma treatment is a rather recent development for changing the surface properties of natural fillers/fibers without significantly affecting their bulk properties (Kalia et al. 2009). A plasma treatment is based on allowing ionized gas with an equal number of positively and negatively charged molecules to react with the surface of the fillers/fibers (Kalia et al. 2009). The treatment conditions used heavily influence the final properties of the treated material, so it is difficult to generalize the final properties (La Mantia and Morreale 2011). Podgorski and Roux (1999) and Podgorski et al. (2000) determined that the type of gas, the treatment duration, the power, and the distance between the samples and the plasma source all influenced the properties of the plasmatreated biofillers/fibers.

\section{PROCESSING METHODS}

Processing methods for the production of composites with plant-based fillers include injection molding, compression molding, and compounding (Rout et al. 2001; Jandas et al. 2012; Dong et al. 2014; Koutsomitopoulou et al. 2014; Hassaini et al. 2017). The method chosen usually depends on how the incorporation of the biofiller/fibers is performed. Woven fibers are usually processed with compression molding, while short fibers are usually injection molded. The end application is also considered when determining which processing method to use. The processing method chosen also reflects the thermal stability of the added biofiller/fiber, as many naturally sourced materials have low thermal stability, limiting processing temperatures to less than approximately $200{ }^{\circ} \mathrm{C}$.

\section{Injection Molding}

Injection molding is a popular processing method for plastics due to the wide variety of materials that can be used and its ease of use. Injection molding is often used in composite applications because it has been shown to improve the fiber dispersion and increase the tensile and flexural properties (Mohanty et al. 2004). Conversely, injection molding can reduce fiber lengths due to the high shear the fibers are exposed to during the extrusion and injection conditions, which in turn changes the properties of the composites.

\section{Compression Molding}

Compression molding is a widely used composite fabrication technique due to its low cost and simplicity. One of the major benefits of compression molding is the amount of control over fiber orientation. The fibers can be randomly orientated, creating a composite with isotropic properties, or they can be selectively orientated, as desired. Certain natural fibers can be difficult to disperse during compression molding.

Every different composite formulation will have a preferred processing method. This can be determined based on previous work with similar polymer matrices and biofiller/fiber type, or by trial and error. Processing techniques include creating layers of 
a fine polymer powder between a biofiller/fiber, sandwiching long fibers between layers, sandwiching short fibers or fillers between layers, dry mixing of components, and multiple layers of both powdered polymer and fibers until the desired weight percentage of material is used (Akil et al. 2011).

\section{Casting}

Casting is a common method used to make films. Casting requires the preparation of a polymer solution, which is poured into a mold and dried under ambient conditions or oven-dried at an elevated temperature. Different materials are used in combination with water or other solvents to form the solution for film production. These materials include starch and PVOH. Starch is a low-cost, versatile, and readily available biodegradable material with excellent film-forming properties (Luchese et al. 2018). Polyvinyl alcohol, however, is a water-soluble polymer that is formed via polymerization and hydrolysis of vinyl alcohol. Polyvinyl alcohol is a biodegradable polymer with high film strength. Plasticizing agents, such as sorbitol and glycerol, are being used to impart flexibility to the final film structures (Luchese et al. 2018).

\section{BIOCOMPOSITES AND FILMS}

Biocomposites derived from both natural fillers/fibers and biodegradable plastics can be classified as biodegradable materials. Despite much research on natural fiber composites, studies related to incorporating food waste into biocomposites are limited. Most of the research related to biocomposites from food waste focuses on biomasses such as coconut, olive, pineapple, and banana. Composites derived from these biomasses and other fruits are discussed in detail, focusing on their mechanical and thermal properties. The properties of the biocomposites depend heavily on the type of polymer matrix used, the treatment of the fibers, the amount of fibers added, the potential addition of compatibilizer, and the process techniques, among other factors. In general, the addition of compatibilizer and surface treatment of the biofiller/fiber typically improved the mechanical properties of the biocomposites.

\section{Fruit Wastes in Composites}

Various fruit wastes, such as blueberry, cranberry, apple, acai berry, rambutan, kiwi, mango, palm fruit, date fruit, and jackfruit, have been used to generate biocomposites and films.

Park et al. (2009) created blueberry, cranberry, and grape pomace biocomposite boards (Fig. 2) with soy flour modified with $\mathrm{NaOH}$. They found that the blueberry pomace had the greatest breaking strength and modulus of elasticity values, as compared to the other pomace biocomposites. The addition of glycerol, acting as a plasticizer, increased the flexibility and decreased the stiffness of the test specimens (Park et al. 2009). The degradation temperature shifted slightly lower with the addition of the blueberry pomace, which was attributed to the lower thermal stability of the biofillers. 

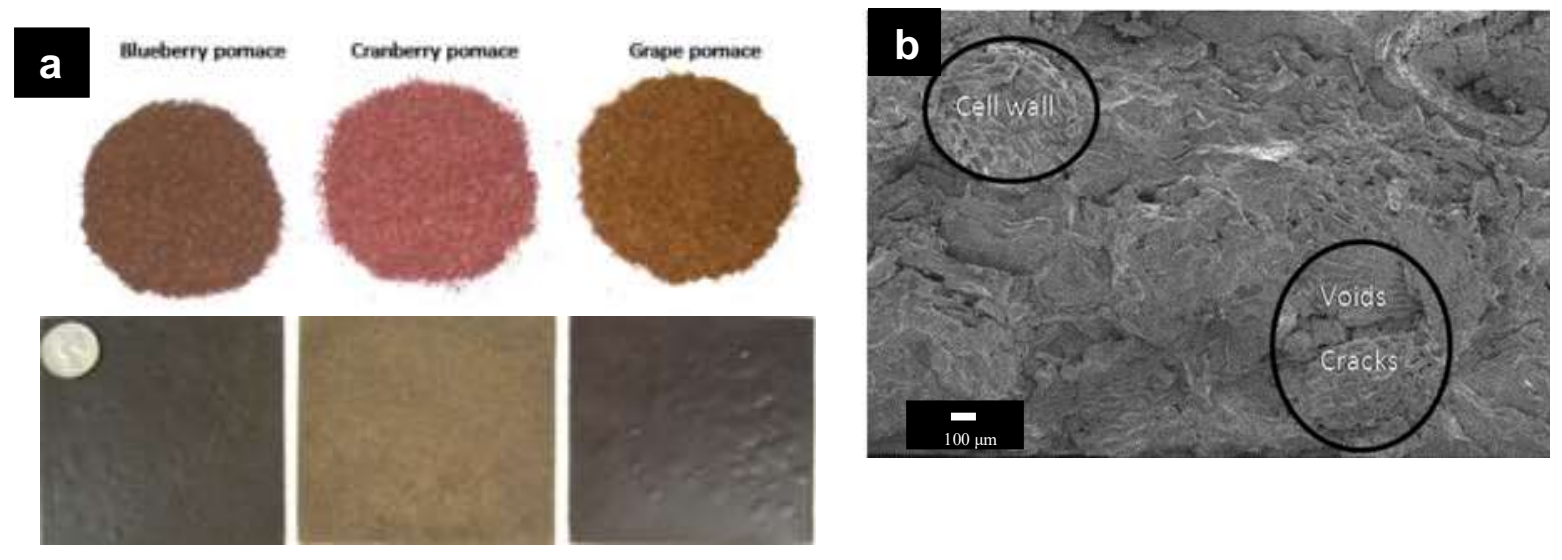

Fig. 2. (a) Blueberry, cranberry, and grape pomaces and their corresponding composites, (b) scanning electron microscope (SEM) image of fracture surface of blueberry pomace board. Reprinted with permission from John Wiley \& Sons: Journal of Applied Polymer Science, (Park et al. 2009), License Number: 4561941149394.

Wataya et al. (2015) developed acai fiber-filled PBAT/PLA biocomposites. They found that $15 \mathrm{wt} \%$ of acai fiber decreased the tensile strength, Young's modulus, and impact strength. However, the elongation at break increased by approximately $17 \%$. The melting temperature remained practically unchanged with the addition of fiber (from $178.0^{\circ} \mathrm{C}$ to $178.5^{\circ} \mathrm{C}$ ) (Wataya et al. 2015). Apple pomace (AP) can be generated from bruised apples, jam production, and juice/cider production. This material is abundant around the world (Shalini and Gupta 2010). Gaikwad et al. (2016) created AP/PVOH films with antimicrobial properties. The AP/ PVOH film with $30 \mathrm{wt} \%$ AP had 40\% scavenging activity on a free radical scavenging assay when using 2,2-diphenyl-1picrylhydrazyl (DPPH), whereas the control with just a PVOH film had no scavenging activity. This result indicated that the AP films had a high antioxidant capacity. The authors attributed this result to the phenolic compounds within the AP (Gaikwad et al. 2016).

AP fiber was studied by Gowman et al. (2019) via scanning electron microscopy (SEM), showing porous and sheet-like morphologies (Fig. 3a). The different morphologies were attributed to the components of the pomace, including skin, seed, and flesh materials (Gowman et al. 2019). Picard et al. (2019) combined AP with biobased PBS (BioPBS) to generate biocomposites, with maleic anhydride-grafted BioPBS as a compatibilizer to improve the mechanical properties. The researchers found that the addition of AP improved the impact strength by more than $120 \%$, even without the addition of compatibilizer. An SEM image of these composites is shown in Fig. 3b. The flexural strength and modulus of the composites with compatibilizer were greater than those of the neat BioPBS. Furthermore, SEM analysis determined that the addition of the compatibilizer improved the interfacial adhesion of the samples (Fig. 3c). The AP-based sustainable biocomposites may find single-use applications for food. 

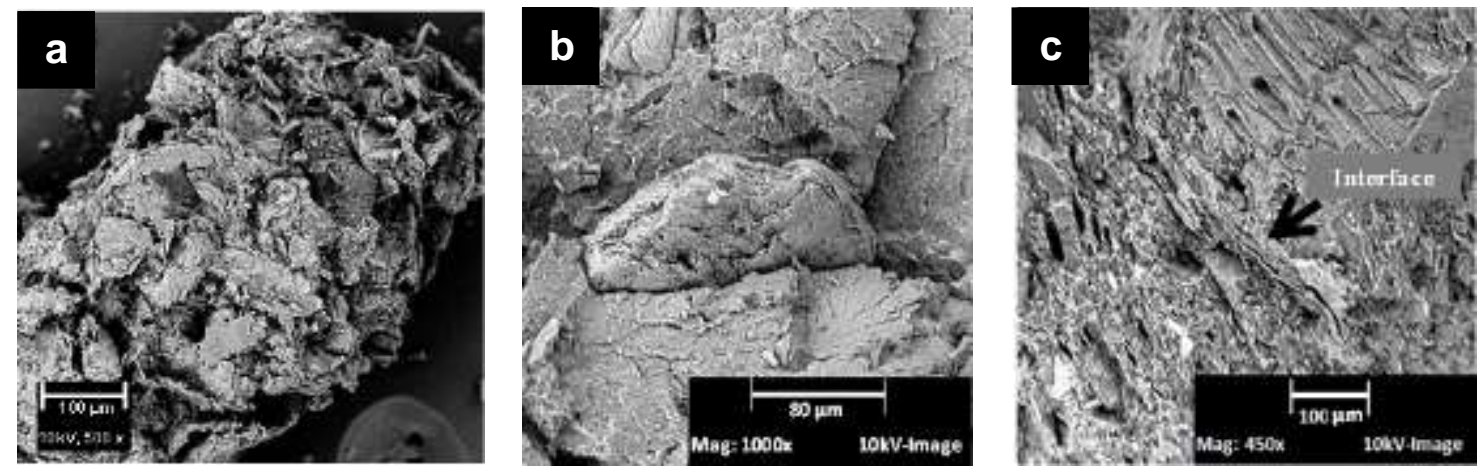

Fig. 3. (a) AP fiber (Gowman et al. 2019), (b) AP composites (Picard et al. 2019), (c) APcompatibilized composites. Reprinted with permission from Springer Nature: Waste and Biomass Valorization, (Picard et al. 2019), License Number: 4560191136299.

Luchese et al. (2018) created blueberry pomace and cassava starch films. They found that the addition of blueberry pomace to their films caused high absorption of wavelengths less than $300 \mathrm{~nm}$, meaning that the pomace was able to protect the films from UV light. The improved UV resistance was attributed to the presence of aromatic compounds in the blueberry pomace, which could help extend the shelf life of foods if used for food packaging applications.

Mittal et al. (2015) created date seed powder (DSP) and PLA/PBAT biocomposites. The authors found that $40 \mathrm{wt} \%$ of DSP increased the tensile modulus of their PBAT biocomposites by more than $300 \%$, while with a PLA matrix, an increase was seen until reaching $20 \mathrm{wt} \%$ (Mittal et al. 2015). The melting point for the PBAT composites decreased with increasing DSP, but it remained almost the same for the PLA composites (Mittal et al. 2014). Voids were present and were explained by moisture evaporation during processing. The authors also noticed oil migration from the DSP but did not notice a change in the mechanical properties of the composites (Mittal et al. 2015). The biodegradation was improved with the addition of the DSP. Increased biocontent is known to improve degradation of composites, and in this case it resulted in bigger cracks and surface degradation in the samples (Mittal et al. 2014).

Rambutan (Nephelium lappaceum) is a tropical fruit that consists of an outer layer, flesh, and seed components. Cast films were prepared with PVOH, glycerol, HMTA, polysorbate 80 as a matrix material, and rambutan skin flour at approximately 8 $\mathrm{wt} \%$ to $32 \mathrm{wt} \%$ filler content. Increasing rambutan flour content resulted in decreased tensile strength. Other properties such as water absorption were increased due to the hydrophilic nature of the filler. This can be less favourable for the use of the composite in food packaging or other applications. However, rambutan did show enhanced adhesion and stronger interaction with the matrix material than did banana skin flour in the same study (Zhong et al. 2011).

Durian (Durio zibethinus) is a commonly consumed fruit in Southeast Asian countries. It consists of $50 \%$ to $65 \%$ flesh components, and the remaining skin and seed materials are waste. Manshor et al. (2014) reported that $\mathrm{NaOH}$-treated durian skin fibers possessed higher impact strength than untreated samples. However, there was little improvement to the overall impact strength of PLA. The authors concluded that the overall performance was comparable to PLA and suggested the use of this filler for costreduction (Manshor et al. 2014). In another study, durian husk fiber was combined with PLA at 15 parts per hundred rubber (phr), $30 \mathrm{phr}, 45 \mathrm{phr}$, and $60 \mathrm{phr}$ (Lee et al. 2018).

Gowman et al. (2019). "Fruit waste biocomposites," BioResources 14(4), 10047-10092. 10063 
The mixtures were compression molded to generate tensile samples. Although tensile strength was lower in the composites as compared to the neat polymer, an increasing tensile strength was observed with increasing fiber content. Furthermore, the tensile modulus increased beyond that of the neat polymer as the fiber content increased. The authors highlighted that the samples were quite brittle (Lee et al. 2018). Thus, further work needs to be done to enhance the interactions of the fiber and matrix and further improve the mechanical properties of the composite.

Table 4. Fruit Pomace and Fruit Waste Composites

\begin{tabular}{|c|c|c|c|c|}
\hline Fruit & Treatment & Matrix & $\begin{array}{l}\text { Preparation } \\
\text { Method }\end{array}$ & Reference \\
\hline $\begin{array}{c}\text { Acai fiber powder } \\
(15 \text { wt\%) }\end{array}$ & Washed & PBAT/PLA & $\begin{array}{l}\text { Injection } \\
\text { molding }\end{array}$ & $\begin{array}{l}\text { Wataya et } \\
\text { al. (2015) }\end{array}$ \\
\hline $\begin{array}{c}\text { Apple } 1 \text { wt } \%, 5 \\
\text { wt\%, } 10 \text { wt } \%, 30 \\
\text { wt } \%\end{array}$ & Untreated & $\mathrm{PVOH}$ & Films & $\begin{array}{l}\text { Gaikwad et } \\
\text { al. (2016) }\end{array}$ \\
\hline $\begin{array}{c}\text { Apple } 20 \text { wt } \%, 30 \\
\text { wt } \%, 40 \text { wt } \%, 50 \\
\text { wt } \%\end{array}$ & Washed & BioPBS & $\begin{array}{l}\text { Injection } \\
\text { molding }\end{array}$ & $\begin{array}{l}\text { Picard et al. } \\
\quad(2019)\end{array}$ \\
\hline Blueberry 20 wt\% & Untreated & $\begin{array}{c}\text { Soy flour or } \\
\text { pectin/xanthan gum } \\
\text { and glycerol }\end{array}$ & $\begin{array}{l}\text { Injection } \\
\text { molding }\end{array}$ & $\begin{array}{l}\text { Park et al. } \\
\quad(2009)\end{array}$ \\
\hline $\begin{array}{c}\text { Blueberry } 4 \text { wt } \%, 8 \\
\text { wt } \%, 12 \text { wt\% }\end{array}$ & Bleached & $\begin{array}{c}\text { Cassava starch and } \\
\text { sorbitol }\end{array}$ & Films & $\begin{array}{l}\text { Luchese et } \\
\text { al. (2018) }\end{array}$ \\
\hline Cranberry 20 wt\% & Untreated & $\begin{array}{c}\text { Soy flour or } \\
\text { pectin/xanthan gum } \\
\text { and glycerol }\end{array}$ & $\begin{array}{l}\text { Injection } \\
\text { molding }\end{array}$ & $\begin{array}{l}\text { Park et al. } \\
\text { (2009) }\end{array}$ \\
\hline $\begin{array}{c}\text { Date seed powder } \\
10 \text { wt } \%, 20 \text { wt } \% \text {, } \\
30 \text { wt } \%, 40 \text { wt } \%\end{array}$ & $\begin{array}{l}\text { Cleaned with } \\
\text { sulfuric acid }\end{array}$ & PLA or PBAT & $\begin{array}{l}\text { Injection } \\
\text { molding }\end{array}$ & $\begin{array}{l}\text { Mittal et al. } \\
\quad(2014, \\
2015)\end{array}$ \\
\hline $\begin{array}{c}\text { Rambutan skin } \\
8 \text { wt } \% \text { to } 32 \text { wt } \%\end{array}$ & Untreated & $\begin{array}{c}\text { PVOH, glycerol, HMTA, } \\
\text { polysorbate } 80\end{array}$ & Film & $\begin{array}{c}\text { Zhong et al. } \\
\quad(2011)\end{array}$ \\
\hline $\begin{array}{c}\text { Durian skin } \\
0 \text { wt } \% \text { to } 40 \text { wt } \%\end{array}$ & $\begin{array}{c}\text { Untreated } \\
\text { and treated } \\
\text { with } 4 \text { wt \% } \\
\mathrm{NaOH}\end{array}$ & PLA & $\begin{array}{l}\text { Injection } \\
\text { molding }\end{array}$ & $\begin{array}{l}\text { Manshor et } \\
\text { al. (2014) }\end{array}$ \\
\hline $\begin{array}{c}\text { Durian husk } 15 \\
\text { phr, } 30 \text { phr, } 45 \\
\text { phr, } 60 \text { phr }\end{array}$ & Untreated & PLA & $\begin{array}{c}\text { Compression } \\
\text { molded test } \\
\text { bars }\end{array}$ & $\begin{array}{l}\text { Lee et al. } \\
\text { (2018) }\end{array}$ \\
\hline $\begin{array}{l}\text { Mango: lump and } \\
\text { almond } \sim 8 \mathrm{wt} \%\end{array}$ & $\begin{array}{c}\text { Treated: } \\
\text { Sanitization }\end{array}$ & PLA & Films & $\begin{array}{c}\text { Lima et al. } \\
(2019)\end{array}$ \\
\hline Kiwifruit skin & Unknown & PLA & $\begin{array}{c}\text { Industrial } \\
\text { production }\end{array}$ & $\begin{array}{l}\text { Graichen et } \\
\text { al. (2017) }\end{array}$ \\
\hline $\begin{array}{c}\text { Palm fruit bunch } \\
12.2 \text { wt } \% \text { to } 63.8 \\
\text { wt\% }\end{array}$ & Washed & PCL & $\begin{array}{l}\text { Compression } \\
\text { molded test } \\
\text { bars }\end{array}$ & $\begin{array}{l}\text { Ahmad et } \\
\text { al. (2018) }\end{array}$ \\
\hline $\begin{array}{c}\text { Jackfruit skin } \\
8 \text { wt\% to } 32 \text { wt } \%\end{array}$ & Untreated & $\begin{array}{c}\text { PVOH, glycerol, } \\
\text { polysorbate 80, HMTA }\end{array}$ & Films & $\begin{array}{l}\text { Ooi et al. } \\
\text { (2011) }\end{array}$ \\
\hline
\end{tabular}

Mango (Mangifera indica L.) is a tropical fruit. Considerable waste is generated as tegument from the outer skin and the seed. Lima et al. (2019) developed films combining PLA with mango seed fiber and/or the tegument. X-ray diffraction analysis (XRD) patterns of the composite displayed a shift in peaks due to the presence of starch 
and cellulose from the samples. Interestingly, the presence of either the seed or tegument increased the tensile strength and Young's modulus over that of the neat PLA film. The increase in modulus was attributed to an anchoring surface generated between the cellulose fibers of the mango parts with PLA, which led to better stress transfer in the system (Lima et al. 2019). Similarly, kiwifruit skin has been combined with PLA to produce a bio-spife, which is a biodegradable utensil combining a spoon and a knife. The bio-spife is manufactured as an alternative to current market spifes generated from polystyrene. The bio-spife was generated with mechanical properties similar to that of spifes made from polystyrene, but it is compostable and hence more sustainable than its petroleum counterpart (Graichen et al. 2017).

Ahmad et al. (2018) combined oil palm empty fruit bunches (OPEFB) with PCL to make biodegradable composites. The thermal stability of the composites decreased, a common result when natural fibers are added to polymer as fillers. Fourier-transform infrared spectroscopy analysis revealed that the interactions between the fiber and matrix material were mainly physical (Ahmad et al. 2018). Overall, the addition of the fillers increased the biocontent and improved the sustainability of the biocomposites. Biodegradable films have also been developed from jackfruit (Artocarpus heterophyllus) waste and PVOH. Ooi et al. (2011) found a decrease in tensile strength with increasing filler loading. However, the Young's modulus increased with increasing jackfruit waste, suggesting that the filler acted as a stiffening agent (Ooi et al. 2011). All fruit pomaces discussed in this section are summarized in the Table 4.

\section{Grape Pomace}

Grape pomace is generated during juice or wine production. This biomass consists of the seeds, skins, flesh, and stems of the grapes. Notably, the chemical composition of the pomace materials would likely be different from study to study; moreover, samples could be fresh or partially fermented. Some winemaking processes require the grape pomace to remain in solution during the winemaking process. This results in the use of the sugars in the samples to fuel the fermentation process. Therefore, pomace generated from juice or wine without fermentation of the pomace contains more sugar. The sugar content of the pomace samples can affect their thermal properties.

Jiang et al. (2011) created both white and red grape pomace biocomposites with grape skin and soy flour or soy protein isolate/PVOH blend. They added stearic acid and epichlorohydrin at different weight percentages to optimize the material properties. Both the white and red grape pomace biocomposites were optimized in terms of breaking strength and modulus of elasticity, water sensitivity, thermal degradation temperature, and soil biodegradation (Jiang et al. 2011). The weight losses for the biocomposites after $30 \mathrm{~d}$ in soil were $50 \%$ and $80 \%$ for the red and white grape skin boards, respectively. The red and white grape skin biocomposites had different properties and optimized formulas due to their different chemical compositions and the processing methods used (Jiang et al. 2011).

Spiridon et al. (2016) created grape seed and PLA biocomposites with $3 \mathrm{wt} \%$ and $10 \mathrm{wt} \%$ grape seeds. The incorporation of grape seeds reduced thermal stability but improved the stiffness of the matrix. The addition of the grape seeds also improved the accelerated aging characteristics of the biocomposites, when compared to neat PLA (Spiridon et al. 2016). The grape seed biocomposites had antimicrobial activity toward Gram-positive and Gram-negative bacteria, which could be advantageous in food packaging applications (Spiridon et al. 2015). Similarly, Gowman et al. (2018) developed 
grape pomace (Fig. 4a) and BioPBS-based biocomposites (Fig. 4b and 4c). They found that $40 \mathrm{wt} \%$ GP with $3 \mathrm{wt} \%$ maleic anhydride-grafted BioPBS (MA-g BioPBS) had the best balance of mechanical and thermal properties. This biocomposite formulation showed $28.4 \%$ and $59 \%$ improvements in flexural and impact strengths, respectively, while the heat distortion temperature increased by $14.3 \%$ (Gowman et al. 2018).
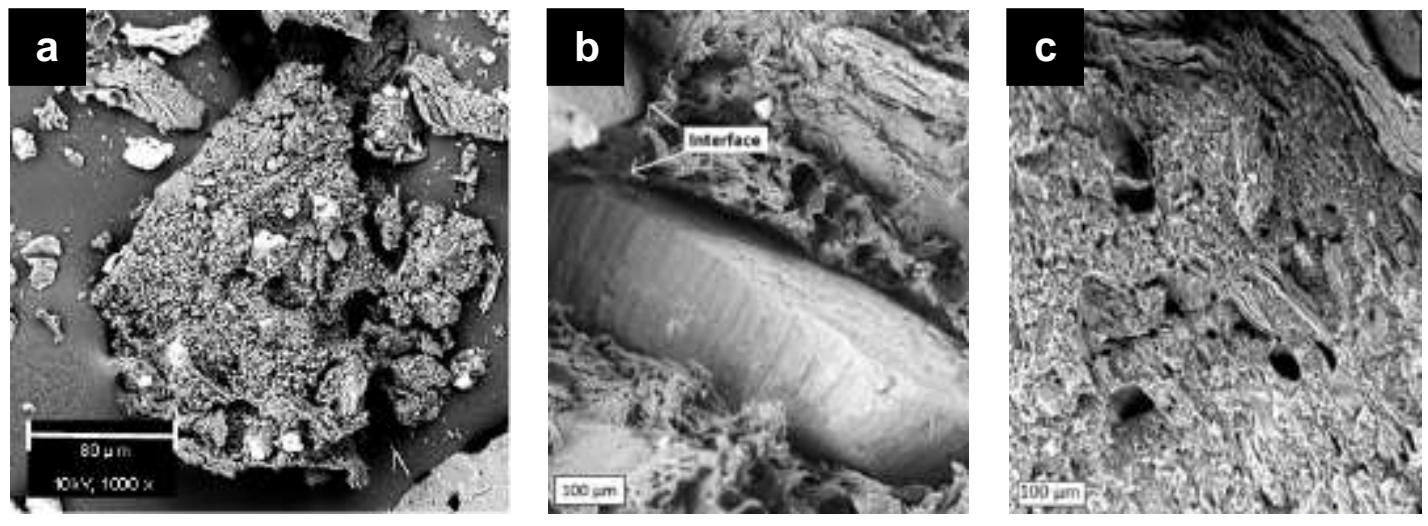

Fig. 4. (a) Grape pomace fiber (b) grape fiber in composites, (c) compatibilized grape pomace composites (Gowman et al. 2019).

Table 5. Grape Filler-based Composites and Films

\begin{tabular}{|c|c|c|c|c|}
\hline Fruit & Treatment & Matrix & $\begin{array}{c}\text { Preparation } \\
\text { Method }\end{array}$ & Reference \\
\hline $\begin{array}{c}\text { Red grape skins } \\
\text { and white grape } \\
\text { skins }\end{array}$ & Untreated & $\begin{array}{c}\text { Soy flour, PVOH, soy protein } \\
\text { isolate, stearic acid, and } \\
\text { epichlorohydrin }\end{array}$ & $\begin{array}{c}\text { Injection } \\
\text { molding }\end{array}$ & $\begin{array}{c}\text { Jiang et al. } \\
(2011)\end{array}$ \\
\hline $\begin{array}{c}\text { Grape } 3 \mathrm{wt} \% \\
\text { and } 10 \mathrm{wt} \%\end{array}$ & Untreated & PLA & $\begin{array}{c}\text { Injection } \\
\text { molding }\end{array}$ & $\begin{array}{c}\text { Spiridon } \text { et al. } \\
(2015,2016)\end{array}$ \\
\hline $\begin{array}{c}\text { Grape } 20 \mathrm{wt} \%, \\
25 \mathrm{wt} \%, 30 \mathrm{wt} \%, \\
40 \mathrm{w} \%, 50 \mathrm{wt} \%\end{array}$ & Untreated & PBS and MA-g BioPBS & $\begin{array}{c}\text { Injection } \\
\text { molding }\end{array}$ & $\begin{array}{c}\text { Gowman et al. } \\
(2018)\end{array}$ \\
\hline $\begin{array}{c}\text { Grape } 98 \mathrm{wt} \% \\
\text { to } 99 \mathrm{wt} \%\end{array}$ & Treated & $\begin{array}{c}\text { Polysaccharide film mixture, } \\
\text { LMP, glycerol }\end{array}$ & Film & $\begin{array}{c}\text { Deng and } \\
\text { Zhao (2011) }\end{array}$ \\
\hline
\end{tabular}

Deng and Zhao (2011) combined fresh red grape pomace with polysaccharides to generate biobased food-grade films. The main constituents in the films were a polysaccharides mixture (of sodium alginate, carrageenan, cell and cellulose gum), and low-methoxyl pectin (LMP). Glycerol was added to some blends to act as plasticizer. Overall, pomace was an effective colouring agent in the films, in addition to acting as a water barrier. Meanwhile, mechanical properties of the biocomposites were satisfactory. Furthermore, the release of phenolic compounds during the film-making process suggested the potential for the film to possess antimicrobial and antioxidant properties with further work (Deng and Zhao 2011). Overall, there have been many studies which incorporate grape pomace into films or composites (Table 5).

\section{Olive}

Olive (Olea europaea) is a fruit grown mostly for oil but also for its wood, leaves, or fruit. Olive pomace, or oil solid waste, is a mixture of skin, pulp, and pit, which are leftovers after pressing the olive for oil. Olive pomace can be re-pressed to produce olive 
pomace oil, with the pomace still remaining as a by-product. Approximately $30 \%$ to $35 \%$ of the weight of the olive is pomace, generating large amounts of low-value by-product (Banat and Fares 2015).

For incorporation into composites, the olive by-products are dried and ground. The filler is washed to remove any impurities, although this is not always done. Most of the biocomposites containing olive filler involve a PLA matrix (Figs. 5a and 5b). Components of the olive incorporated include pit, husk, and pomace/waste/cake.
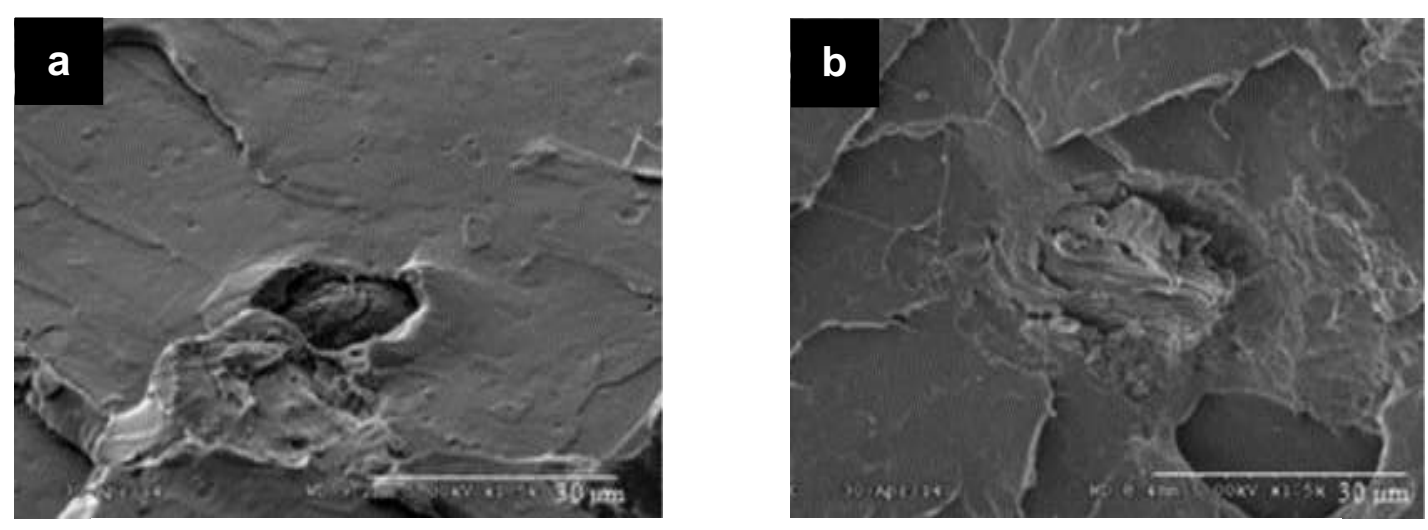

\begin{tabular}{|c|c|c|c|}
\hline Sample & $\begin{array}{l}\text { Young's modulus } \\
(\mathrm{MPa})\end{array}$ & $\begin{array}{l}\text { Tensile Strength } \\
(\mathrm{MPa})\end{array}$ & $\begin{array}{c}\text { Strain at break } \\
(\%)\end{array}$ \\
\hline PLA extruded & $2060 \pm 23$ & $60 \pm 2$ & $6.0 \pm 0.5$ \\
\hline PLA/OSW $(80 / 20)$ & $1888 \pm 25$ & $55 \pm 3$ & $3.6 \pm 0.6$ \\
\hline PLA/OSW/0.7CE & $2234 \pm 30$ & $62 \pm 2$ & $4.3 \pm 0.3$ \\
\hline PLA/OSW/1 & $2320 \pm 21$ & $64 \pm 2$ & $4.2 \pm 0.7$ \\
\hline
\end{tabular}

Fig. 5. (a) Olive waste and PLA, (b) olive waste and PLA with chain extender, (c) mechanical properties. Reprinted with permission from John Wiley \& Sons: Polymer Composites, (Khemakhem et al. 2018b), Copyright 2016, License Number: 4557810973384.

Koutsomitopoulou et al. (2014) created biocomposites with olive pits and PLA. They investigated the effects of particle size and weight fractions on the mechanical and physical properties. An increase in tensile modulus and a small decrease in tensile strength were reported with the addition of $20 \mathrm{wt} \%$ olive pit powder (Koutsomitopoulou et al. 2014). Olive husk biocomposites have been made with various matrix materials, including poly(butylene succinate-co-butylene adipate) (PBSA) (Tserki et al. 2006), PLA (Isadounene et al. 2017), and PHBV (Hassaini et al. 2017). Tserki et al. (2005) treated the olive husk with acetylation and propionylation processes to esterify the olive husk and decrease its hydrophobicity. They found that the incorporation of $30 \mathrm{wt} \%$ olive filler increased the tensile modulus, water absorption, and the degradation rate. However, tensile strength was reduced. They also found that the treated olive had half as much water absorption as compared to the untreated olive (Tserki et al. 2006). Isadounene et al. (2017) showed that untreated olive husk with PLA increased the Young's modulus and that the incorporation of olive filler increased the storage modulus but decreased the elongation at break and the tensile strength (Isadounene et al. 2017). The authors then tested the effect of particle treatment on accelerated aging. The olive husk underwent an alkali treatment in $\mathrm{NaOH}$ and had improved mechanical properties but a lower 
degradation rate, as compared to its untreated counterparts (Isadounene et al. 2018). Hassaini et al. (2017) investigated the effect of silane-treated olive husk on water contact angle, crystallinity, and tensile properties and compared with untreated olive husk. The addition of $20 \mathrm{wt} \%$ olive husk caused the crystallinity of PHBV to increase by $33.9 \%$ and $14.7 \%$ in treated and untreated biocomposites, respectively (Hassaini et al. 2017). The gas permeability through samples increased with treated olive husks, with oxygen permeability increasing by $164 \%$ and water vapor permeation by $352 \%$ (Hassaini et al. 2017).

Table 6. Olive Filler-based Biocomposites

\begin{tabular}{|c|c|c|c|c|}
\hline Filler & Treatment & Matrix & Preparation Method & Reference \\
\hline $\begin{array}{l}\text { Olive pit powder } \\
5 \mathrm{wt} \%, 10 \mathrm{wt} \% \text {, } \\
15 \mathrm{wt} \%, 20 \mathrm{wt} \%\end{array}$ & Untreated & PLA & Injection molding & $\begin{array}{l}\text { Koutsomitopoulou et al } \\
\text { (2014) }\end{array}$ \\
\hline $\begin{array}{c}\text { Olive husk flour } \\
10 \text { wt } \%, 20 \text { wt } \% \text {, } \\
30 \text { wt } \%\end{array}$ & Untreated & PLA & Injection molding & $\begin{array}{l}\text { Isadounene et al. } \\
\qquad(2017)\end{array}$ \\
\hline $\begin{array}{c}\text { Olive solid } \\
\text { waste } 20 \mathrm{wt} \%\end{array}$ & Untreated & $\begin{array}{c}\text { PLA and } \\
\text { acrylate rubber } \\
\text { particles (ACR) } \\
\text { wt } \%, 2.5 \text { wt } \% \text {, } \\
5 \text { wt } \%, 10 \text { wt } \%\end{array}$ & $\begin{array}{l}\text { Compounding } \rightarrow \\
\text { compression molding }\end{array}$ & $\begin{array}{c}\text { Khemakhem et al. } \\
(2018 a)\end{array}$ \\
\hline $\begin{array}{l}\text { Olive pomace } 0 \\
\text { wt } \% \text { to } 20 \text { wt } \%\end{array}$ & Untreated & $\begin{array}{c}\text { Plasticized } \\
\text { wheat gluten }\end{array}$ & $\begin{array}{c}\text { Compounding } \rightarrow \\
\text { film formation }\end{array}$ & Boudria et al. (2018) \\
\hline \multicolumn{5}{|c|}{ Surface treated } \\
\hline $\begin{array}{l}\text { Olive husk flour } \\
\quad 30 \text { wt\% }\end{array}$ & $\begin{array}{l}\text { Acetic or } \\
\text { propionic } \\
\text { anhydride }\end{array}$ & PBSA & $\begin{array}{l}\text { Compounding } \rightarrow \\
\text { compression molding }\end{array}$ & $\begin{array}{l}\text { Tserki et al. (2005, } \\
\text { 2006) }\end{array}$ \\
\hline $\begin{array}{l}\text { Olive pomace } 0 \\
\text { wt } \% \text { to } 20 \text { wt } \%\end{array}$ & $\begin{array}{c}\text { Acetone, MA, } \\
\mathrm{NaOH}\end{array}$ & $\begin{array}{l}\text { Wheat gluten } \\
\text { plasticized by } \\
35 \% \text { glycerol }\end{array}$ & $\begin{array}{c}\text { Compounding } \rightarrow \\
\text { compression molding }\end{array}$ & $\begin{array}{l}\text { Hammoui et al. } \\
\qquad(2015)\end{array}$ \\
\hline $\begin{array}{l}\text { Olive husk flour } \\
20 \mathrm{wt} \%\end{array}$ & Silane & PHBV & $\begin{array}{l}\text { Compounding } \rightarrow \\
\text { compression molding }\end{array}$ & $\begin{array}{l}\text { Hassaini et al. } \\
(2017)\end{array}$ \\
\hline $\begin{array}{c}\text { Olive solid } \\
\text { waste } 20 \mathrm{wt} \%\end{array}$ & Hexane & $\begin{array}{l}\text { PLA, PCL, and } \\
\text { poly(styrene- } \\
\text { acrylic-co- } \\
\text { glycidyl } \\
\text { methacrylate) } \\
\end{array}$ & $\begin{array}{l}\text { Compounding } \rightarrow \\
\text { compression molding }\end{array}$ & $\begin{array}{l}\text { Khemakhem et al. } \\
(2018 b)\end{array}$ \\
\hline $\begin{array}{l}\text { Olive husk flour } \\
20 w t \%\end{array}$ & $\mathrm{NaOH}$ & PLA & Injection molding & $\begin{array}{c}\text { Isadounene et al. } \\
(2018)\end{array}$ \\
\hline
\end{tabular}

Olive pomace, cake, and waste all refer to the by-product produced from olive oil production. Researchers have investigated the effects of olive pomace in different biopolymer matrixes, including gluten, PLA, and PLA/PCL blend. Hammoui et al. (2015) and Boudria et al. (2018) investigated the effect of olive pomace in a wheat gluten-based matrix. Hammoui et al. (2015) investigated the effects of olive pomace treated with acetone, esterification with maleic anhydride (MA), and mercerization with $\mathrm{NaOH}$. The chemical modifications did not improve the mechanical properties significantly, and the treatments decreased the water absorption of the biocomposites (Hammoui et al. 2015). Boudria et al. (2018) also incorporated olive pomace with wheat gluten. They found that the moisture absorption was improved (with less moisture 
absorption being better for film applications) with increasing addition of olive pomace, compared to neat wheat gluten (Boudria et al. 2018), similar to the findings reported by Hammoui et al. (2015). They attributed the reduction in water absorption to increased lignin content in the wheat gluten, which would reduce the overall hydrophilicity of the blend (Boudria et al. 2018). The difference between the two studies can be explained by the treatment of the olive pomace. Chemical treatments are well known for reducing water absorption because of the changed surface functionalities of the filler. This has been confirmed in other research (Li et al. 2007).

It is common for olive-based biocomposites to exhibit decreased tensile strength as compared to neat polymers because the added biofiller/biofiber can introduce stress concentration factors into a polymer matrix. The inefficient stress transfer between the polymer matrix and biofillers/fibers causes the tensile strength to decrease (Fu et al. 2008). Some researchers have found that water absorption decreased with the incorporation of treated fibers (Tserki et al. 2006), but some reported an opposite water absorption trend (Hammoui et al. 2015). The increase in water absorption was explained by an increased amount of lignin present, as lignin is hydrophobic, so the addition of it would decrease water absorption. This work and others with olive pomace have found many creative ways to generate composites; a summary of these works is located in Table 6.

\section{Banana}

Banana is an edible fruit produced by different plants from the Musa genus. Banana fibers $(\mathrm{BF})$ are a by-product from banana farming and have little value (Merlini et al. 2011). Banana plants do not regrow more bananas once harvested, so they generate large amounts of waste biomass (Li et al. 2010). The part of the plant that is left over is typically referred to as a "pseudo-stem" (Li et al. 2010). The leftover part of the plant is typically allowed to decompose in the field, resulting in environmental pollution. This can be remediated by utilizing the fibers in value-added applications like biocomposites.

Most of the literature on banana biocomposites focuses on treated BF, usually with silane and some with both silane and $\mathrm{NaOH}$. As previously discussed, these treatments help make the fibers less hydrophilic, therefore decreasing water absorption and increasing matrix adhesion between the filler and the polymer in question. Research on BF composites has been focused on the use of PLA as the matrix, with uncompatibilized and compatibilized biocomposites.

Asaithambi et al. (2014) investigated the effect of surface treatment with benzoyl peroxide on banana/sisal fibers in PLA (Fig. 6). A fraction of $30 \mathrm{wt} \%$ of fibers was blended with $70 \mathrm{wt} \%$ of PLA. The authors found that the chemical treatment enhanced the fiber/matrix interaction and increased the tensile strength, flexural strength, modulus, and impact strength, compared to neat PLA. Jandas et al. (2011) investigated the effects of surface treatments (washing, $\mathrm{NaOH}$, acetylation, and silane) on the tensile strength of BF. They found that the silane-treated fibers had the greatest tensile strength, modulus, and elongation at break. Acetylation, $\mathrm{NaOH}$ treatment, and washing all decreased the tensile modulus and elongation at break. However, the tensile strengths of the samples with different treatments were more variable. The silane-treated samples showed greater tensile strength than the washed samples, followed by the $\mathrm{NaOH}$-treated samples, with the lowest tensile strength belonging to biocomposites with acetylated fibers (Jandas et al. 2013c). Jandas et al. (2011) also investigated the effect of surface treatment with $\mathrm{NaOH}$ and silane on the properties of banana fiber/PLA biocomposites. They found that a 
BF loading of $30 \mathrm{wt} \%$ yielded optimal mechanical properties. Surface treatment with bis(3-triethoxy silyl propyl) tetrasulfane (Si69) had the best thermomechanical results (Jandas et al. 2011). Surface-treated biocomposites had improvements in both tensile strength and modulus, along with greater glass transition temperature $\left(T_{\mathrm{g}}\right)$, crystallization temperature $\left(T_{\mathrm{c}}\right)$, and melting temperature $\left(T_{\mathrm{m}}\right)$ (Jandas et al. 2011). The surface treatment also increased the storage modulus and decreased the degradation rate for samples placed in a Burkholderia cepacia and potato dextrose broth. These observations correlate with the enhanced interfacial adhesion and lower microbial activity due to silane's antibacterial activity (Jandas et al. 2012). The same group used micromechanical models such as Hirsh's, a modified Bowyer-Bader (Bowyer and Bader 1972), and Brodnyan to model the biocomposites' moduli. Overall, these models showed good agreement with the results obtained, but they predicted the silane treatment more accurately because the treatment improved the interphase between the filler and matrix (Jandas et al. 2013a).
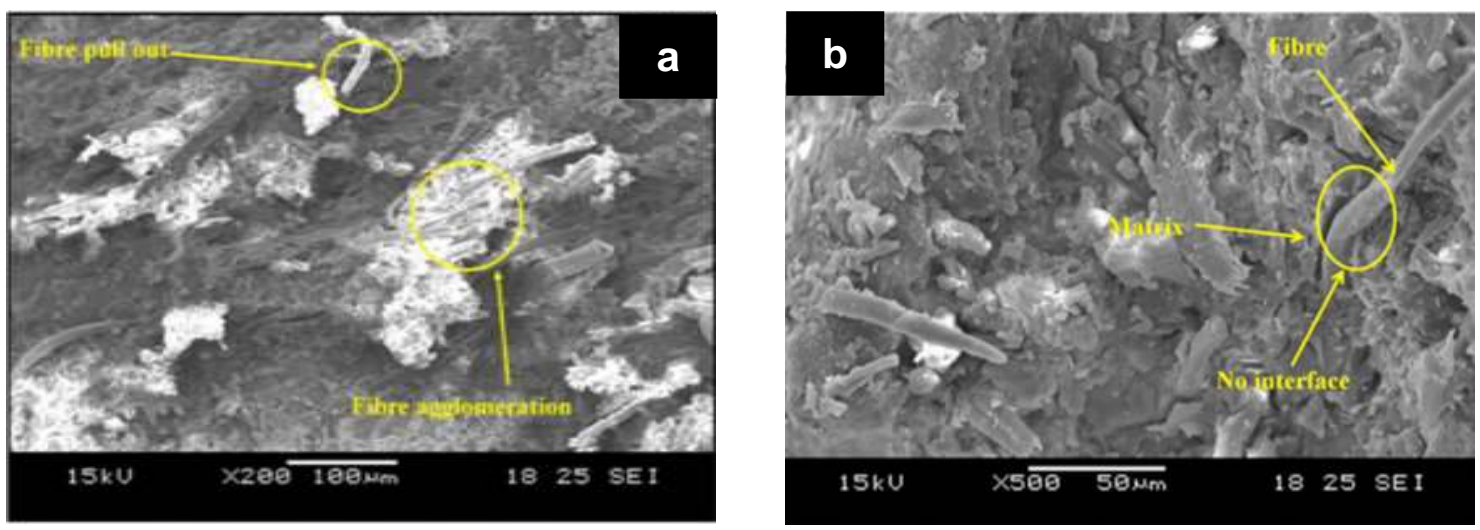

Fig. 6. Banana fibers with PLA: (a) tensile and (b) flexural samples. Reprinted with permission from Springer Nature: Fibers and Polymers, (Asaithambi et al. 2014), Copyright 2014, License Number: 4561970447709.

Jandas et al. (2013b) further investigated the effect of organically modified nanoclay on PLA/surface-treated BF. The incorporation of $3 \mathrm{wt} \%$ nanoclay increased $T_{\mathrm{g}}$ from $57.3{ }^{\circ} \mathrm{C}$ to $62.6{ }^{\circ} \mathrm{C}$ (Jandas et al. 2013b), which was attributable to a decrease in free volume in the system, from the cross-linking from the intermolecular attraction between the diols on the nanoclay and the $\mathrm{C}=\mathrm{O}$ bonds present in the PLA (Tjong and Bao 2005). Thermal stability increased along with the storage modulus. The final degradation temperature of the nanoclay $\mathrm{BF}$ composites was $372{ }^{\circ} \mathrm{C}$, which is $30{ }^{\circ} \mathrm{C}$ greater than the neat PLA. This increase was attributed to the high thermal stability of the nanoclay and to the interaction between the matrix and BF (Alvarez and Vázquez 2006). The increase in storage modulus was attributed to the large interfacial area and interactions between the PLA and silane-treated BF due to the incorporation of nanoclay. The flammability was decreased to $8.4 \mathrm{~mm} / \mathrm{min}$ for the nanoclay biocomposites, compared to $10.0 \mathrm{~mm} / \mathrm{min}$ for the neat PLA. Jandas et al. (2013c) took 70/30 PLA/silane-treated BF blend and added 3 $\mathrm{wt} \%$ nanoclay to make injection-molded samples. The samples were molded cutlery, which had lower density and improved mechanical properties compared to PP or PE. This result demonstrated that the researched biocomposite samples had a potential purpose and an intended application (Jandas et al. 2013c).

Majhi et al. (2010) combined banana fibers (Fig. 6) with PLA and found that the 
tensile strength increased with increasing fiber loadings. However, elongation at break and impact strength decreased with increasing untreated and treated BF (Majhi et al. 2010). The BF and PLA showed a noticeable gap between the filler and the matrix, which may explain the decrease in material properties. When $1 \mathrm{wt} \%$ of MA was added to the $\mathrm{BF} / \mathrm{PLA}$ blends, increases in tensile modulus, tensile strength, elongation at break, and impact strength were observed, compared to their uncompatibilized counterparts. The authors also found that increasing the MA content to $3 \mathrm{wt} \%$ or $5 \mathrm{wt} \%$ caused the tensile modulus to reach a plateau, which could be considered a critical interfacial concentration, beyond which no change in properties would be seen with additional amounts of compatibilizer (Liu et al. 2003).

Sajna et al. (2016) created biocomposites with PLA and PLA-grafted (PLA-g) glycidyl methacrylate (GMA) as a compatibilizer with treated BF. Silane-treated BF at 30 wt $\%$ loading was incorporated with $70 \mathrm{wt} \%$ PLA. Then, various weight percentages (5 $\mathrm{wt} \%, 10 \mathrm{wt} \%, 15 \mathrm{wt} \%$, and $20 \mathrm{wt} \%$ ) of PLA-g GMA were added (Sajna et al. 2016). The compatibilized biocomposites showed improvements in their mechanical properties compared to neat PLA and their uncompatibilized counterparts. The degradation temperature improved with GMA, along with the moisture absorption resistance. The researchers then incorporated nanoclay into the PLA/silane-treated BF matrix without the GMA. The nanoclay increased the thermal degradation temperature compared to the neat PLA and the biocomposites without the nanoclay (Sajna et al. 2017a). The thermal stability was improved, and the combustion rate decreased, which was attributed to the fiber and nanoclay producing char, acting as a thermal barrier (Sajna et al. 2017a). The researchers then explored the effect of nanoclay on compatibilized biocomposites with GMA (10 wt $\%, 15 \mathrm{wt} \%, 20 \mathrm{wt} \%$, and $25 \mathrm{wt} \%$ ) and nanoclay. The thermal stability of the biocomposites was further enhanced with the addition of GMA. The compatibilized composite showed the slowest burning rate, at $13.1 \mathrm{~mm} / \mathrm{min}$, compared to $15.8 \mathrm{~mm} / \mathrm{min}$ for neat PLA (Sajna et al. 2017b). Overall, it was determined that silane-treated BF with the incorporation of nanoclay and compatibilized PLA created the best biocomposites in terms of mechanical and thermal properties.

Banana biocomposites created by Asaithambi et al. (2014) showed improved mechanical properties compared to those of the neat polymer. In fact, there were $175 \%$, $400 \%, 158 \%, 151 \%$, and $106 \%$ increases in tensile strength, tensile modulus, flexural strength, flexural modulus, and impact strength, respectively, for the treated BF composites (Asaithambi et al. 2014). Jandas et al. (2015) investigated various different BF compositions and noted that surface treated fibers showed improvement compared to the untreated filler. They also noted that the thermal stability improved with the addition of nanoclay (Alvarez et al. 2004; Jandas et al. 2013b). The addition of compatibilizers, MA and GMA, respectively, also improved the mechanical properties of banana biocomposites (Majhi et al. 2010; Sajna et al. 2016).

Banana skin has been made into flour and combined in varying weights (approximately $8 \mathrm{wt} \%$ to $32 \mathrm{wt} \%$ ) with PVOH, HTMA, glycerol, and polysorbate 80 to produce sustainable films. Some of the biofilms' properties were hindered by the addition of banana skin flour, showing decreased tensile strength, increased water absorption, and increased water vapour transmission rate (Zhong et al. 2011). Uniquely, Zhong et al. (2011) examined the natural weathering characteristics of the films, with natural weathering analysis of samples subjected to environmental factors such as sunlight, rain, dew, and wind. They found that, although the tensile strength and elongation at break decreased after 1 month of weathering, the tensile moduli of blends with banana skin 
flour increased. This result was attributed to the breaking down of long molecular chains in the PVOH materials (Zhong et al. 2011). A summary of the processes to fabricate these composites and others from banana can be found in Table 7.

Table 7. Banana Fiber-based Biocomposites

\begin{tabular}{|c|c|c|c|c|}
\hline Filler & Treatment & Matrix & Preparation Method & Reference \\
\hline $\begin{array}{l}\text { BF } 10 \text { wt } \%, \\
20 \text { wt } \%, 30 \\
\text { wt } \%, 40 \text { wt } \%\end{array}$ & $\mathrm{NaOH}$ & $\begin{array}{c}\text { PLA, MA, and } \\
\text { GTA }\end{array}$ & $\begin{array}{l}\text { Compounding } \rightarrow \\
\text { compression molding }\end{array}$ & $\begin{array}{l}\text { Majhi et al. } \\
\quad(2010)\end{array}$ \\
\hline $\begin{array}{c}\text { BF } 10 \text { wt } \%, \\
20 \text { wt } \%, 30 \\
\text { wt } \%, 40 \text { wt } \%\end{array}$ & $\mathrm{NaOH}$ and silanes & PLA & $\begin{array}{l}\text { Compounding } \rightarrow \\
\text { compression molding }\end{array}$ & $\begin{array}{c}\text { Jandas et } \\
\text { al. }(2011, \\
2012 \\
2013 a \\
2013 c) \\
\end{array}$ \\
\hline BF $30 w t \%$ & $\begin{array}{c}\text { Washed in } \\
\text { detergent, } \mathrm{NaOH}, \\
\text { silane }\end{array}$ & $\begin{array}{c}\text { PLA and } \\
\text { organically } \\
\text { modified nanoclay }\end{array}$ & Injection molding & $\begin{array}{l}\text { Jandas et } \\
\text { al. (2013b) }\end{array}$ \\
\hline BF 30 wt $\%$ & Benzoyl peroxide & PLA & Injection molding & $\begin{array}{l}\text { Asaithambi } \\
\text { et al. (2014) }\end{array}$ \\
\hline $\begin{array}{c}\text { BF } 5 \text { wt } \%, 10 \\
\text { wt } \%, 15 \text { wt } \% \text {, } \\
20 \text { wt } \%\end{array}$ & Silane & $\begin{array}{l}\text { PLA and PLA-g } \\
\text { GMA }\end{array}$ & Injection molding & $\begin{array}{l}\text { Sajna et al. } \\
\quad(2016)\end{array}$ \\
\hline BF 30 wt\% & Silane & $\begin{array}{c}\text { PLA/ } 3 \text { wt\% } \\
\text { nanoclay }\end{array}$ & Injection molding & $\begin{array}{l}\text { Sajna et al. } \\
(2017 a)\end{array}$ \\
\hline BF 20 wt\% & Silane & $\begin{array}{c}\text { PLA, PLA-g GMA, } \\
\text { and nanoclay } 3 \\
\text { wt } \%\end{array}$ & Injection molding & $\begin{array}{l}\text { Sajna et al. } \\
(2017 \mathrm{~b})\end{array}$ \\
\hline $\begin{array}{c}\text { Banana skin } \\
8 \text { wt } \% \text { to } 32 \\
\text { wt } \%\end{array}$ & Untreated & $\begin{array}{c}\text { PVOH, glycerol, } \\
\text { HMTA, } \\
\text { polysorbate } 80\end{array}$ & Film & $\begin{array}{l}\text { Zhong et al. } \\
\text { (2011) }\end{array}$ \\
\hline
\end{tabular}

\section{Coconut}

Coconut (Cocos nucifera) is a member of the palm tree family and has edible fruit. Coconut fibers (CF), or coir, are located in the middle of the husk and the outer shell in a coconut. The price of the fibers is low, as they are a by-product of other coconut products such as coconut milk and flesh. Out of all coconuts produced, it is estimated that approximately $10 \%$ of the husks are used as fibers (Faruk et al. 2012). The majority of research on coconut biocomposites focuses on PLA, PBS, EVOH, polyester amide, and gluten polymers.

Nam et al. (2011) incorporated coir fibers into PBS at different weight percentages, between $10 \mathrm{wt} \%$ and $30 \mathrm{wt} \%$, of filler. The fibers were treated with $\mathrm{NaOH}$ before being compression molded with PBS. A ratio of $75 \mathrm{wt} \%$ to $25 \mathrm{wt} \%$ of PBS to CF showed the best mechanical properties, with increases of $54.5 \%$ for tensile strength, $141.9 \%$ for tensile modulus, $45.7 \%$ for flexural strength, and $97.4 \%$ for flexural modulus, when compared to the neat PBS (Nam et al. 2011). The authors concluded that up to 25 wt $\%$ of fibers could be incorporated in a PBS matrix before the mechanical properties started to decrease.

Rosa et al. (2009) incorporated $15 \mathrm{wt} \%$ coir into starch/EVOH blends at $50 \mathrm{wt} \%$ starch, $30 \mathrm{wt} \% \mathrm{EVOH}, 10 \mathrm{wt} \%$ water, and $10 \mathrm{wt} \%$ glycerol. They performed water, alkali, and bleaching treatments on the CF. The treated fibers had greater tensile strength than those untreated and showed greater tensile strength and tensile modulus than 
starch/EVOH, along with greater thermal stability (Rosa et al. 2009). The authors concluded that the addition of $\mathrm{CF}$ into the biocomposite yielded enhanced material properties compared to the neat polymer.

Hemsri et al. (2012) created wheat gluten composites with 15 wt\% CF treated by alkali or alkali and silane and $85 \mathrm{wt} \%$ wheat gluten. The silane-treated biocomposites had better properties than the alkali-treated $\mathrm{CF}$ biocomposites. The addition of treated fibers increased the stress at the first failure point on the stress-strain curve, and fiber treatment improved the adhesion with the matrix material, reducing the fiber pull-out observed in the uncompatibilized samples (Hemsri et al. 2012).

Rout et al. (2001) made CF and polyester amide biocomposites. Four surface treatments were evaluated including alkali, cyanoethylation, bleaching, and vinyl grafting. The optimal fiber content was $50 \mathrm{wt} \%$, in terms of mechanical properties. All of the surface treatments improved the mechanical properties compared to neat polymer, with the cyanoethylation treatment yielding the greatest tensile strength (Rout et al. 2001). Biocomposites with 7\% methyl methacrylate grafted coir had superior mechanical properties in comparison to the other composites (Rout et al. 2001).

Suardana et al. (2011) fabricated biocomposites with $40 \mathrm{wt} \% \mathrm{CF}$ and $60 \mathrm{wt} \%$ PLA. Coconut fibers were rinsed, treated with $\mathrm{NaOH}$ followed by acrylic acid, and then rinsed. The biocomposites treated with acrylic acid had the least water absorption compared to untreated or only $\mathrm{NaOH}$-treated fibers (Suardana et al. 2011). Soaking in acrylic acid for $0.5 \mathrm{~h}$ yielded the greatest tensile and flexural strengths of the biocomposites after $3 \mathrm{~h}, 6 \mathrm{~h}$, and $192 \mathrm{~h}$ of water immersion (Suardana et al. 2011). Salmah et al. (2013) also used acrylic acid treatment to modify the surface of coconut shell powder. They found that the treated biocomposites had greater tensile strength and modulus of elasticity, but the elongation at break was reduced (Salmah et al. 2013). The surface treatment was found to enhance the matrix-filler interaction and increase the thermal stability.

Jang et al. (2012) created biocomposites with oxygen plasma-treated CF and PLA. Fractions of $5 \mathrm{wt} \%$ and $10 \mathrm{wt} \%$ untreated and treated CF were incorporated into a PLA matrix. The tensile strength and Young's modulus increased, and shrinkage of the biocomposites decreased with increasing fractions after treatment of the fibers (Jang et al. 2012). Dong et al. (2014) treated $\mathrm{CF}$ with $\mathrm{NaOH}$ and created CF/PLA composites. They found that $20 \mathrm{wt} \% \mathrm{CF}$ yielded the optimal balance of mechanical properties. The alkali treatment improved all mechanical properties compared to the untreated fiber, which the authors attributed to the improved fiber-matrix adhesion and fiber wettability (Dong et al. 2014). They also found that the thermal stability of the biocomposites decreased when treated, due to the lower thermal stability of the fibers incorporated. The addition of the fibers increased the degradation rate, which the authors attributed to the residual $\mathrm{NaOH}$ causing breakup of the PLA chains, in turn leading to faster degradation (Dong et al. 2014).

Some researchers have found that the incorporation of $\mathrm{CF}$ into various biopolymer matrices yielded an improvement in certain mechanical properties (Nam et al. 2011; Suardana et al. 2011). Thermal stability was also seen to improve with the addition of treated fibers (Rosa et al. 2009; Salmah et al. 2013). The addition of compatibilizer further improved the mechanical properties (Rout et al. 2001), and a decrease in shrinkage was observed with increasing weight percentages of CF (Jang et al. 2012). A greater degradation rate in a composting medium was seen when CF was introduced into a PLA matrix, indicating improved composting. This was attributed to the 
increased water diffusion through the sample due to the hydrophilicity of the fillers (Dong et al. 2014). A summary of all biocomposites generated from coconut is displayed in Table 8.

Table 8. Coconut Filler- and Fiber-based Biocomposites

\begin{tabular}{|c|c|c|c|c|}
\hline Filler & Treatment & Matrix & Preparation Method & Reference \\
\hline $\begin{array}{c}\text { Coconut shell } \\
\text { powder, } 15 \text { wt } \% \text {, } \\
30 \text { wt } \%, 45 \text { wt } \% \text {, } \\
60 \text { wt } \%\end{array}$ & Silane & PLA & $\begin{array}{l}\text { Compounding } \rightarrow \\
\text { compression molding }\end{array}$ & $\begin{array}{l}\text { Chun et al. } \\
\text { (2012) }\end{array}$ \\
\hline \multicolumn{5}{|c|}{ Surface treated } \\
\hline $\begin{array}{c}\text { Coir, } 30 \text { wt\%, } 40 \\
\text { wt\%, } 50 \text { wt\%, } 60 \\
\text { wt } \%\end{array}$ & $\begin{array}{l}\mathrm{NaOH}, \\
\text { bleaching }\end{array}$ & $\begin{array}{l}\text { Biodegradable } \\
\text { polyester amide }\end{array}$ & $\begin{array}{l}\text { Sandwiched mats, } \\
\text { compression molded }\end{array}$ & $\begin{array}{l}\text { Rout et al. } \\
\text { (2001) }\end{array}$ \\
\hline Coir, 15 wt\% & $\begin{array}{c}\mathrm{NaOH}, \\
\text { bleaching }\end{array}$ & $\begin{array}{l}\text { EVOH, starch, } \\
\text { water, glycerol }\end{array}$ & Injection molding & $\begin{array}{c}\text { Rosa et al. } \\
(2009)\end{array}$ \\
\hline Coir, 40 wt\% & $\begin{array}{l}\mathrm{NaOH} \text { and } \\
\text { acrylic acid }\end{array}$ & PLA & Compression molding & $\begin{array}{l}\text { Suardana } \\
\text { et al. (2011) }\end{array}$ \\
\hline $\begin{array}{c}\text { Coir, } 10 \text { wt\%, } 15 \\
\text { wt\%, } 20 \text { wt\%, } 25 \\
\text { wt } \%, 30 \text { wt\% }\end{array}$ & $\mathrm{NaOH}$ & PBS & Compression molding & $\begin{array}{c}\text { Nam et al. } \\
(2011)\end{array}$ \\
\hline CF 15 wt\% & $\mathrm{NaOH}$, silane & Wheat gluten & Compression molding & $\begin{array}{l}\text { Hemsri et } \\
\text { al. (2012) }\end{array}$ \\
\hline $\begin{array}{c}\text { Coir } 5 \text { wt } \%, 10 \\
\text { wt } \%,\end{array}$ & Treated & $\begin{array}{c}\text { Oxygen } \\
\text { plasma/PLA }\end{array}$ & Compression molded & $\begin{array}{l}\text { Jang et al. } \\
\text { (2012) }\end{array}$ \\
\hline $\begin{array}{l}\text { Coconut shell } \\
\text { powder, } 0 \text { wt } \% \text {, } \\
15 \text { wt } \%, 30 \text { wt } \% \text {, } \\
45 \text { wt } \%, 60 \text { wt } \%\end{array}$ & $\begin{array}{l}\text { Untreated and } \\
\text { acrylic acid }\end{array}$ & PLA & Compression molding & $\begin{array}{l}\text { Salmah et } \\
\text { al. (2013) }\end{array}$ \\
\hline $\begin{array}{c}\text { Coir, } 5 \text { wt\%, } 10 \\
\text { wt\%, } 20 \text { wt\%, } 30 \\
\text { wt } \%\end{array}$ & $\mathrm{NaOH}$ & PLA & Compression molding & $\begin{array}{l}\text { Dong et al. } \\
\quad(2014)\end{array}$ \\
\hline
\end{tabular}

\section{Pineapple}

Pineapple (Ananas comosus) is an abundant tropical plant that generates a lot of lignocellulosic fibers (Fig. 7). Currently, pineapple leaf fibers (PALFs) are considered a by-product of pineapple farming, so they can be obtained at a low cost (Faruk et al. 2012). Pineapple leaf fiber biocomposites show the most variability in terms of surface treatments and matrices out of all the biofillers/fibers explored. Untreated, $\mathrm{NaOH}$-treated, and silane-treated PALFs have been added to different matrices, including PLA, PBS, polyester amide (PEA), soy flour, and tapioca.

Kim et al. (2012) created pineapple flour/PLA biocomposites. The flour was blended with MA-grafted PLA (MA-g PLA), with 3 wt\% MA-g PLA incorporated with different weight percentages of filler. It was found that $30 \mathrm{wt} \%$ of flour yielded the best overall mechanical properties (Kim et al. 2012). Furthermore, $T_{\mathrm{g}}$ increased with the addition of flour, while $T_{\mathrm{m}}$ was divided into two peaks, likely due to the quick decrease in molecular weight and rearrangement of polymer chains (Kim et al. 2012). The heat deflection temperature also increased with the flour and MA, from $56.8{ }^{\circ} \mathrm{C}$ to $70.6{ }^{\circ} \mathrm{C}$, indicating improved stress transfer (Kim et al. 2012).

Liu et al. (2005) created soy flour, PEA, and chopped PALF composites. The flour was mixed at a 70:30 weight ratio to PEA and then extruded with $15 \mathrm{wt} \%$ or 30 
wt $\%$ PALF. The 70:30 blend with 30 wt $\%$ PALF was then combined with a compatibilizer at $5 \mathrm{wt} \%$ (PEA grafted with GMA (Liu et al. 2005). The addition of 30 wt $\%$ PALF significantly increased the mechanical properties. The improvements were even more pronounced with the addition of compatibilizer. The water absorption of the compatibilized samples was lower than that of the uncompatibilized counterparts, which was attributed to the improvement of interfacial adhesion and stress transfer between the matrix and fiber (Liu et al. 2005).

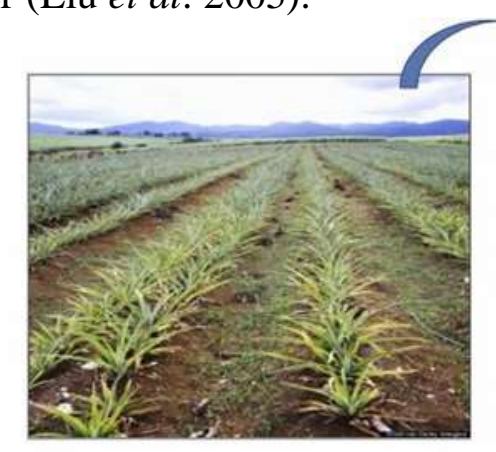

Pineapple field

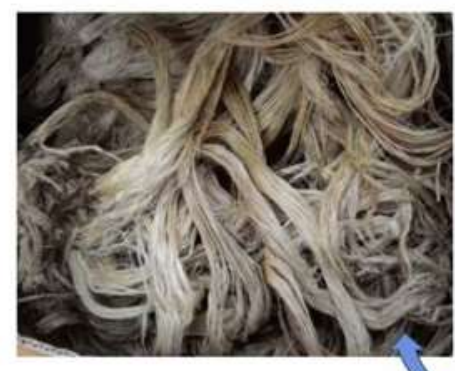

Pineapple leaf fibres

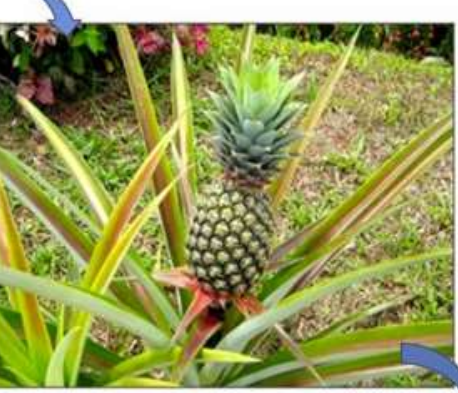

Fruit of pineapple

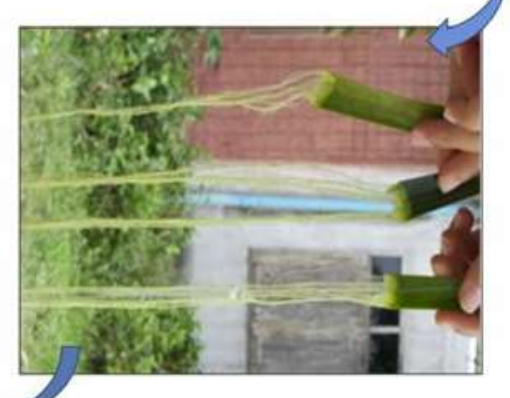

Fibres from pineapple leaves

Fig. 7. Pineapple field, fruit, and leaf fibers (Asim et al. 2015)

Siakeng et al. (2019) fabricated coconut/pineapple fiber and PLA biocomposites (Fig. 8). They incorporated a 1:1, 3:7, or 7:3 ratio of coconut to pineapple at $30 \mathrm{wt} \%$ or $30 \mathrm{wt} \%$ of either into a PLA matrix. The authors found that the hybrid combinations of the fibers performed better than the individual fiber types alone (Siakeng et al. 2019). The authors attributed this result to the combination of fibers overcoming the inherent disadvantages of each of the fiber types individually. The addition of CF decreased tensile and flexural strength, while the opposite effect was seen with the addition of PALF (Siakeng et al. 2019). A ratio of $15 \mathrm{wt} \% \mathrm{CF}$ with $15 \mathrm{wt} \%$ PALF and $70 \mathrm{wt} \%$ PLA had the best tensile and flexural properties, along with the storage modulus and loss modulus. 

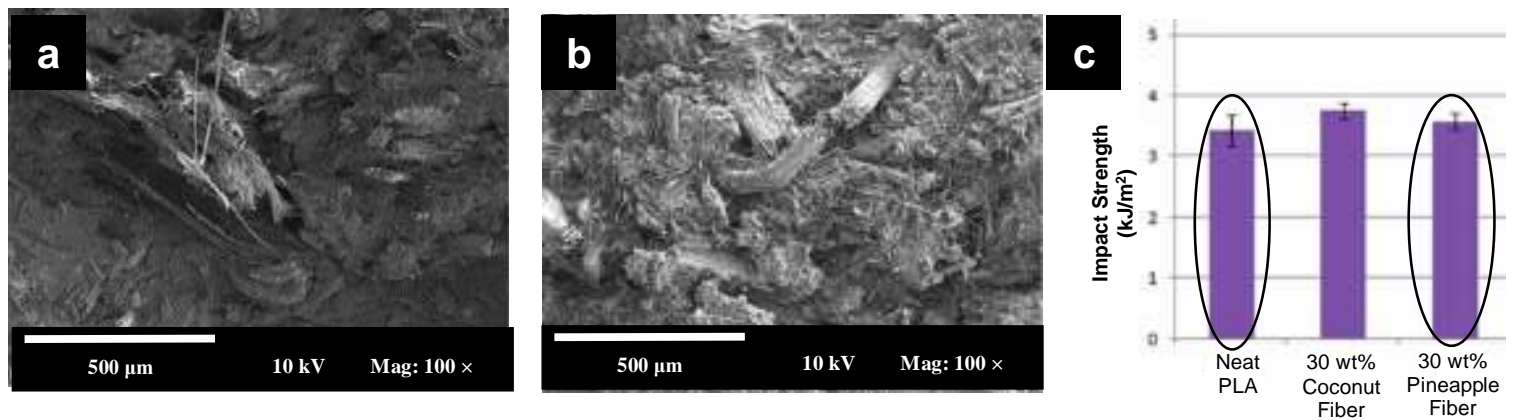

Fig. 8. Pineapple fiber composites: (a) tensile fracture surface, (b) flexural fractural surface, (c) impact properties where the error bar is the standard deviation. Reprinted with permission from John Wiley \& Sons: Polymer Composites, (Siakeng et al. 2019), Copyright 2018, License Number: 4557640115394.

Jaafar et al. (2018) fabricated PALF (at $10 \mathrm{wt} \%, 20 \mathrm{wt} \%, 30 \mathrm{wt} \%$, and $40 \mathrm{wt} \%$ ) and PLA biocomposites. The optimal percentage of filler was $30 \mathrm{wt} \%$, with improvements in tensile strength, tensile modulus, flexural strength, and impact strength of $42 \%, 165 \%, 69 \%$, and 10\%, respectively (Jaafar et al. 2018). Huda et al. (2008) examined the effects of untreated and treated PALF fibers in a PLA matrix. They performed alkali, silane, and combined alkali/silane surface treatments on the PALF. Biocomposites of $30 \mathrm{wt} \%, 40 \mathrm{wt} \%$, and $50 \mathrm{wt} \%$ PALF were created. The biocomposites created from the treated fibers had significantly improved mechanical and thermal properties (Huda et al. 2008). These increases were attributed to the strong interaction between the added PALF and the PLA. Dynamic mechanical analysis revealed a greater storage modulus, indicating greater interfacial bond strength and fiber matrix adhesion. This result was attributed to the chemical bonds between the PALF and the matrix due to the reactive groups present on the fiber surface (Huda et al. 2008).

Shih et al. (2014) fabricated treated PALF and recycled chopstick (wood) fibers in a PLA or PBS matrix. The fibers were treated with an alkaline solution and a silane treatment. The fibers at $30 \mathrm{wt} \%$ (7:3 ratio of PALF to chopstick: $21 \mathrm{wt} \%$ PALF and 9 wt $\%$ chopstick) yielded the best overall mechanical properties. The tensile strengths of the PBS and PLA increased by $121.7 \%$ and $66.1 \%$, respectively (Shih et al. 2014). The flexural strengths increased for both PBS and PLA by approximately 66\%, and the heat deflection temperatures of the PBS and PLA increased by approximately $33.6 \%$ and $75 \%$, respectively (Shih et al. 2014).

Ramli et al. (2016) created PALF and PLA biocomposites with both treated and untreated PALF with long and short fibers. With the long fibers, the flexural strength and modulus increased from 56.4 to $114 \mathrm{MPa}$ and 4.3 to $5.7 \mathrm{GPa}$ when treated, respectively, with $30 \mathrm{wt} \%$ loading. The authors attributed this increase to the alkaline treatment increasing the surface roughness of the fibers, causing a rough surface at the matrix-fiber interface (Ramli et al. 2016). 
Table 9. Pineapple Fiber-based Biocomposites

\begin{tabular}{|c|c|c|c|c|}
\hline Filler & Treatment & Matrix & Preparation Method & Reference \\
\hline PALF 40 wt $\%$ & $\begin{array}{l}\mathrm{NAOH} \text { and } \\
\text { silane }\end{array}$ & PLA & Compression molding & $\begin{array}{l}\text { Huda et al. } \\
(2008)\end{array}$ \\
\hline $\begin{array}{c}\text { Pineapple skin flour } \\
30 \mathrm{wt} \%\end{array}$ & Untreated & $\begin{array}{l}\text { PLA and } \\
\text { MA-g PLA }\end{array}$ & Injection molding & $\begin{array}{c}\text { Kim et al. } \\
(2012)\end{array}$ \\
\hline $\begin{array}{l}\text { PALF/chopstick fiber } \\
10 \text { wt } \% \text { to } 30 \text { wt } \%\end{array}$ & $\mathrm{NaOH}$ & $\begin{array}{l}\text { PBS and } \\
\text { dicumyl } \\
\text { peroxide }\end{array}$ & Injection molding & $\begin{array}{l}\text { Shih et al. } \\
\text { (2014) }\end{array}$ \\
\hline $\begin{array}{c}\text { PALF } 15 \text { wt } \%, 30 \\
\text { wt } \%\end{array}$ & Untreated & $\begin{array}{l}\text { Soy flour, } \\
\text { PEA, and } \\
\text { PEA-grafted } \\
\text { GMA }\end{array}$ & Injection molding & $\begin{array}{l}\text { Liu et al. } \\
\text { (2005) }\end{array}$ \\
\hline PALF 30 wt \% & $\begin{array}{l}\text { Untreated } \\
\text { and } \mathrm{NaOH}\end{array}$ & PLA & $\begin{array}{c}\text { Compounding } \rightarrow \\
\text { compression molding }\end{array}$ & $\begin{array}{l}\text { Ramli et al. } \\
\text { (2016) }\end{array}$ \\
\hline $\begin{array}{l}\text { PALF/CF (1:1, 7:3, } \\
3: 7) 30 \text { wt } \% \text {, CF } 30 \\
\text { wt } \%, \text { PALF } 30 \text { wt } \%\end{array}$ & Untreated & PLA & $\begin{array}{c}\text { Compounding } \rightarrow \\
\text { compression molding }\end{array}$ & $\begin{array}{l}\text { Siakeng et } \\
\text { al. (2019) }\end{array}$ \\
\hline $\begin{array}{c}\text { PALF } 10 \text { wt } \%, 20 \\
\text { wt } \%, 30 \text { wt } \%, 40 \text { wt } \%\end{array}$ & Untreated & $\begin{array}{c}\text { Tapioca } \\
\text { biopolymer }\end{array}$ & $\begin{array}{l}\text { Compounding } \rightarrow \\
\text { compression molding }\end{array}$ & $\begin{array}{l}\text { Jaafar et } \\
\text { al. }(2018)\end{array}$ \\
\hline
\end{tabular}

The addition of PALF to a polymer matrix improved the mechanical properties, compared to a neat biopolymer (Jaafar et al. 2018). The mechanical properties were further improved with the addition of compatibilizer into the PALF/biopolymer system (Liu et al. 2005; Kim et al. 2012) or with surface treatment of the PALF (Huda et al. 2008; Ramli et al. 2016). The heat deflection temperatures of the biocomposites increased with compatibilizer or surface treatment (Kim et al. 2012; Shih et al. 2014). Siakeng et al. (2019) found that a combination of both CF and PALF yielded better mechanical properties than either of the fiber types individually (Siakeng et al. 2019). This could be an interesting area of further research, combining fibers based on their strengths and weaknesses to develop composites with desired properties. A summary of this work and all works with pineapple fiber is shown in Table 9.

\section{ENVIRONMENTAL CONSIDERATIONS}

There are different considerations regarding the environmental impacts of agricultural and food wastes. Some environmental concerns are related directly to waste generation, such as composting, incineration, or landfilling. Other impacts from the agriwaste correspond to the secondary processing for chemicals or fuels. It is essential to consider the effects on soil, air, and waterways from waste products and greenhouse gas emissions.

\section{Current Uses of Fruit Waste}

Work by Khan et al. (2015) highlights various uses for fruit wastes (Fig. 9). Although their work focuses on South Africa, similar processes are applicable around the world. A sustainable bio-economy requires the use of materials in industrial applications such as bio-materials, bio-chemicals, and bio-energy, as well as sustainable environmental management processes for liquid and solid wastes (Khan et al. 2015). 


\section{Environmental Impact}

Fruits are a major factor in the agri-food processing industry. In the United States of America, the food processing industry requires one fifth of all energy consumed (Diakosavvas 2017). Furthermore, a substantial amount of energy is put forth to transport the materials from farms to processing facilities and then to their final destinations, as well as for refrigeration of the fruits (Diakosavvas 2017). Therefore, it is important to maximize the use of the residue or pomace materials. A reduction in energy consumption should be followed by an overall decrease in greenhouse gas emissions (Diakosavvas 2017).

Traditional methods of discarding fruit waste include placing the material in landfills, use as a feed source for livestock, and compositing (Negro et al. 2017). Some pomace materials are further refined for chemical extracts, such as pectin from apples (Shalini and Gupta 2010). Other methods of discarding waste are resource regenerative methods, including thermomechanical and biological energy production. The thermomechanical processes use pyrolysis or incineration of the materials to generate heat and electricity; biological processes such anaerobic digestion and co-digestion produce bio-products and fuel (Negro et al. 2017). However, some of these processes can yield harmful by-products such as carbon dioxide and methane, which may contribute to greenhouse gas emissions (Negro et al. 2017). 


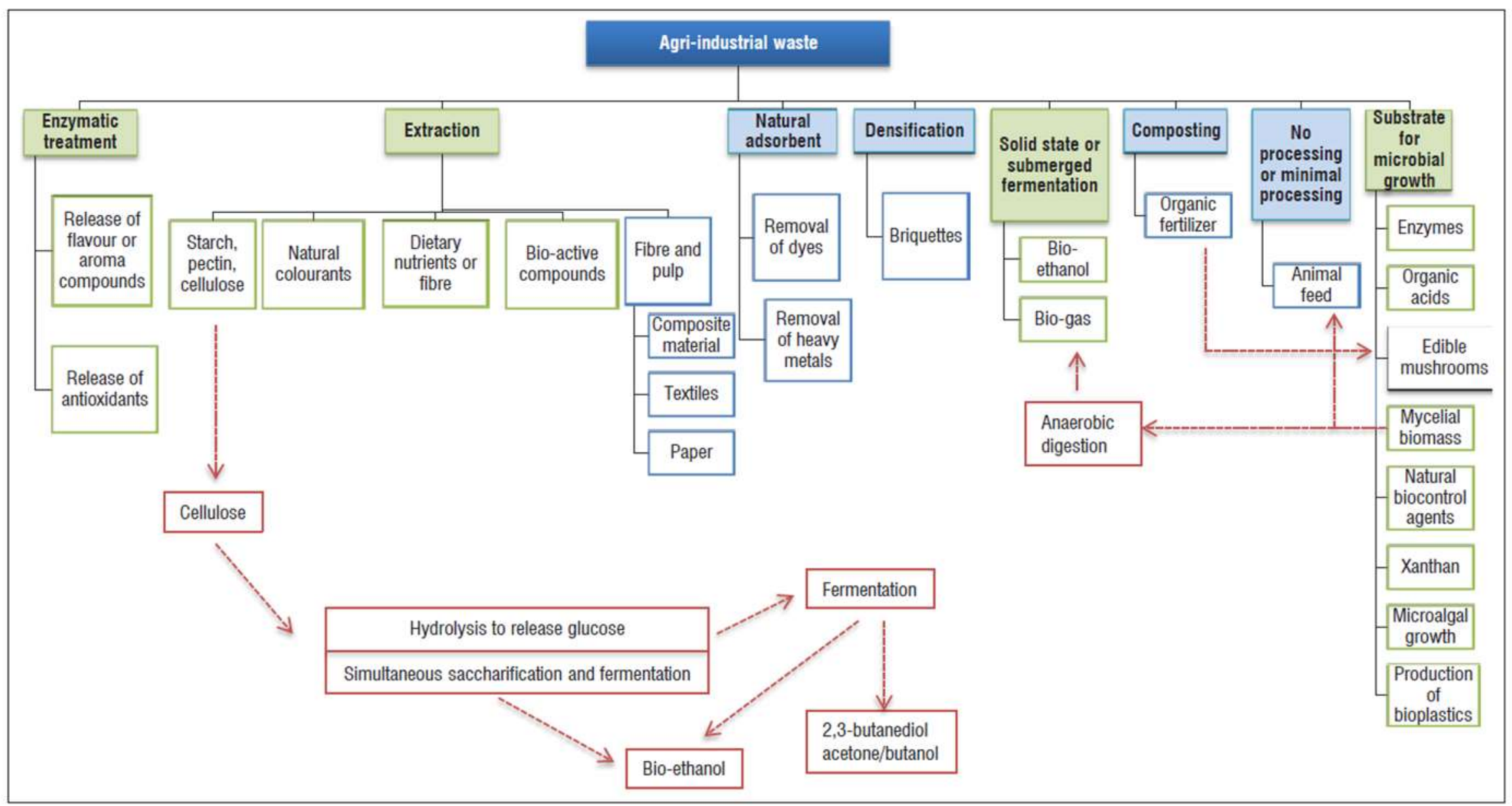

Fig. 9. Description of agri-waste (with major focus on fruit) uses and management systems in South Africa (Khan et al. 2015) 


\section{Feasibility of Manufacturing}

To ensure valorization of fruit waste, optimal methods to store and process the materials are required so that they are accessible all year round. Some fruit wastes are generated at the time of harvest, while others are generated throughout the year. Olive and grape pomaces, for example, are available year-round as they remain in storage prior to processing, thus providing steady supply of this material for value-added applications (Gowman et al. 2019). Other fruit such as bananas are produced year-round and therefore are considered as a continuous source of fruit waste (Asim et al. 2015).

Once fruit wastes, such as apple and grape pomaces are generated, they are stored temporarily in a cold cellar to reduce the rate of spoilage and then dried as soon as possible (Gowman et al. 2019). The materials can be air-dried if aerated frequently, which is a cost- effective drying method. Wastes are typically dried to a moisture content of less than $1 \mathrm{wt} \%$ and sealed in cool storage to minimize spoilage. This approach ensures that the materials can be transported and utilized in industry with ease.

\section{Life Cycle Assessment for Fruit Wastes}

A literature review by Gassara et al. (2011) compared disposal methods for AP via a life cycle assessment. Comparing AP from Quebec, Canada, destined for incineration, landfill, fermentation, composting, or animal feed (Table 10), the authors determined that fermentation contributed the least to emissions, in terms of $\mathrm{CO}_{2}$ equivalence (Gassara et al. 2011). The addition of AP or natural fibers prolongs the life of the sample and does not result in immediate placement of the material into one of the categories mentioned below. In fact, the use of fruit waste in composites sequesters the carbon and prevents the release of carbon dioxide until the biocomposites and films are at the end of their functional lives. The end of life of the materials would most likely result in landfill, but the materials will degrade naturally and more easily with greater natural filler content. However, there are other methods of disposal.

Table 10. Comparison of Carbon Emissions from Various Disposal Streams of AP in Canada

\begin{tabular}{|c|c|c|c|c|c|c|}
\hline Fruit & $\begin{array}{c}\text { Incineration } \\
\text { (tonnes of } \\
\mathrm{CO}_{2} \\
\text { equivalent) }\end{array}$ & $\begin{array}{c}\text { Landfill } \\
\text { (tonnes of } \mathrm{CO}_{2} \\
\text { equivalent) }\end{array}$ & $\begin{array}{c}\text { Fermentation } \\
\text { (tonnes of } \mathrm{CO}_{2} \\
\text { equivalent) }\end{array}$ & $\begin{array}{c}\text { Composting } \\
\text { (tonnes of } \mathrm{CO}_{2} \\
\text { equivalent) }\end{array}$ & $\begin{array}{c}\text { Animal Feed } \\
\text { (tonnes of } \mathrm{CO}_{2} \\
\text { equivalent) }\end{array}$ & Location \\
\hline $\begin{array}{c}\text { AP } \\
\text { Gassara } \\
\text { et al. } \\
(2011)\end{array}$ & 1017.95 & 1670.13 & 822.64 & 1155.55 & 873.96 & $\begin{array}{c}\text { Quebec, } \\
\text { Canada }\end{array}$ \\
\hline
\end{tabular}

According to the literature, if the biobased polymers are burned at the end of life, then the sample is considered carbon neutral. Carbon neutrality occurs because the carbon dioxide generated from burning the materials is then used by the biomass during photosynthesis (Iwata 2015). Therefore, valorization of the waste product creates energy-conscious products which are sustainable for years to come.

\section{Life Cycle Assessment for Fruit Waste Composites}

It is important to reiterate that the biodegradability of non-biodegradable polymer is not affected by the addition of natural fillers or fibers. Although there is improved 
sustainability from the production of composites, those with non-biodegradable matrix material most likely would end up in incineration or landfill at their end of life, as recycling of these materials is not feasible. The more ideal option is to combine natural fillers from fruit wastes with biodegradable polymers (Mohanty et al. 2018). This approach alleviates the risk of contaminating the recycling streams, and allows for industrial composting.

\section{CONCLUSIONS}

1. Fruit wastes have the potential to be successfully incorporated into many different biodegradable polymer matrices for a wide variety of applications. The use of fruit waste helps valorize the by-product, generating revenue for farmers and lower material costs for composite manufacturers.

2. These biocomposites have the advantage of being biodegradable and lower cost than their neat biopolymer counterparts, due to the incorporation of the low-cost biofiller/fiber.

3. A major hurdle to overcome is the creation of biocomposites having a good balance of mechanical and thermal properties, while maintaining the low-cost benefits associated with the fruit waste. Surface treatments of biofillers/fibers enhance these properties, but a greater cost is associated with these treatments. Compatibilizers have also been effective in improving mechanical and thermal properties, but they also have a high associated cost.

4. Further work on utilizing fruit waste biocomposites in real-life applications would help advance the field as well as the impact of these materials on the environment. Valorization of fruit waste biomass in biocomposites will continue to gain favor in industry and research, as the materials provide a renewable and sustainable solution to global plastic concerns.

\section{ACKNOWLEDGMENTS}

The authors would like to thank the Natural Sciences and Engineering Research Council (NSERC), Canada Discovery Grants Project \#400320; the Ontario Ministry of Agriculture, Food and Rural Affairs (OMAFRA), University of Guelph, Bioeconomy Industrial Uses Research Program Theme Project \#030177; and the Ontario Ministry of Economic Development, Job Creation and Trade, Ontario Research Fund, Research Excellence (OFR-RE09-078) Project \#053970 for financial support to perform this research.

Conflicts of Interest: The authors have no known conflicts of interest.

\section{REFERENCES CITED}

Agrawal, R., Saxena, N. S., Sharma, K. B., Thomas, S., and Sreekala, M. S. (2000). 
"Activation energy and crystallization kinetics of untreated and treated oil palm fibre reinforced phenol formaldehyde composites," Materials Science and Engineering: A 277(1-2), 77-82. DOI: 10.1016/S0921-5093(99)00556-0

Ahmad, A. F., Abbas, Z., Obaiys, S. J., and Zainuddin, M. F. (2018). "Effect of untreated fiber loading on the thermal, mechanical, dielectric, and microwave absorption properties of polycaprolactone reinforced with oil palm empty fruit bunch biocomposites," Polymer Composites 39(S3), E1778-E1787. DOI: 10.1002/pc.24792

Aht-Ong, D., and Charoenkongthum, K. (2002). "Thermal properties and moisture absorption of LDPE/banana starch biocomposite films," Journal of Metals, Materials and Minerals 12(1), 1-10.

Aimi, N. N., Anuar, H., Manshor, M. R., Nazri, W. B. W., and Sapuan, S. M. (2014). "Optimizing the parameters in durian skin fiber reinforced polypropylene composites by response surface methodology," Industrial Crops and Products 54, 291-295. DOI: 10.1016/j.indcrop.2014.01.016

Akil, H. M., Omar, M. F., Mazuki, A. A. M., Safiee, S., Ishak, Z. A. M., and Abu Bakar, A. (2011). "Kenaf fibre reinforced composites: A review," Materials \& Design 32(89), 4107-4121. DOI: 10.1016/j.matdes.2011.04.008

Altendorf, S. (2019). Major Tropical Fruits Market Review 2017, Food and Agriculture Organization of the United Nations, Rome, Italy.

Alvarez, V. A., and Vázquez, A. (2006). "Influence of fiber chemical modification procedure on the mechanical properties and water absorption of MaterBi-Y/sisal fiber composites," Composites Part A: Applied Science and Manufacturing 37(10), 1672 1680. DOI: 10.1016/j.compositesa.2005.10.005

Alvarez, V. A., Fraga, A. N., and Vázquez, A. (2004). "Effects of the moisture and fiber content on the mechanical properties of biodegradable polymer-sisal fiber biocomposites," Journal of Applied Polymer Science 91(6), 4007-4016. DOI: 10.1002/app.13561

Asaithambi, B., Ganesan, G., and Ananda Kumar, S. (2014). "Bio-composites: Development and mechanical characterization of banana/sisal fibre reinforced poly lactic acid (PLA) hybrid composites," Fibers and Polymers 15(4), 847-854. DOI: 10.1007/s12221-014-0847-y

Asim, M., Abdan, K., Jawaid, M., Nasir, M., Dashtizadeh, Z., Ishak, M. R., and Hoque, M. E. (2015). "A review on pineapple leaves fibre and its composites," International Journal of Polymer Science 2015. DOI: 10.1155/2015/950567

ASTM D6400-04 (2004). "Standard specification for compostable plastic," ASTM International, West Conshohocken, PA. DOI: 10.1520/D6400-04

ASTM D5338-15 (2015). "Standard test method for determining aerobic biodegradation of plastic materials under controlled composting conditions, incorporating thermophilic temperatures," ASTM International, West Conshohocken, PA. DOI: 10.1520/D5338-15

ASTM D5988-18 (2018). "Standard test method for determining aerobic biodegradation of plastic materials in soil," ASTM International, West Conshohocken, PA. DOI: 10.1520/D5988-18

Auras, R., Lim, L.-T., Selke, S. E. M., and Tsuji, H. (eds.) (2010). Poly(lactic acid): Synthesis, Structures, Properties, Processing, and Applications, John Wiley \& Sons, Inc., Hoboken, NJ, USA. DOI: 10.1002/9780470649848

Avella, M., Martuscelli, E., and Raimo, M. (2000). "Properties of blends and composites based on poly(3-hydroxy)butyrate (PHB) and poly(3-hydroxybutyrate- 
hydroxyvalerate) (PHBV) copolymers," Journal of Materials Science 35(3), 523-545. DOI: 10.1023/A:1004740522751

Baker, M. I., Walsh, S. P., Schwartz, Z., and Boyan, B. D. (2012). "A review of polyvinyl alcohol and its uses in cartilage and orthopedic applications," Journal of Biomedical Materials Research Part B: Applied Biomaterials 100B(5), 1451-1457. DOI: $10.1002 / \mathrm{jbm} . b .32694$

Banat, R., and Fares, M. M. (2015). "Olive oil waste filled high density polyethylene biocomposite: Mechanical, morphological and water absorption properties," International Journal of Composite Materials 5(5), 133-141. DOI: 10.5923/j.cmaterials.20150505.05

Blažzević, N., Kolbah, D., Belin, B., Šunjić, V., and Kajfež, F. (1979). "Hexamethylenetetramine, a versatile reagent in organic synthesis," Synthesis 1979(3), 161-176. DOI: 10.1055/s-1979-28602

Bledzki, A. K., Mamun, A. A., and Volk, J. (2010). "Barley husk and coconut shell reinforced polypropylene composites: The effect of fibre physical, chemical and surface properties," Composites Science and Technology 70(5), 840-846. DOI: 10.1016/j.compscitech.2010.01.022

Bledzki, A. K., Mamun, A. A., Lucka-Gabor, M., and Gutowski, V. S. (2008). "The effects of acetylation on properties of flax fibre and its polypropylene composites," Express Polymer Letters 2(6), 413-422. DOI: 10.3144/expresspolymlett.2008.50

Boudria, A., Hammoui, Y., Adjeroud, N., Djerrada, N., and Madani, K. (2018). "Effect of filler load and high-energy ball milling process on properties of plasticized wheat gluten/olive pomace biocomposite," Advanced Powder Technology 29(5), 1230-1238. DOI: 10.1016/j.apt.2018.02.015

Bowyer, W. H., and Bader, M. G. (1972). "On the reinforcement of thermoplastics by imperfectly aligned discontinuous fibres," Journal of Materials Science 7(11), 13151321. DOI: $10.1007 / \mathrm{BF} 00550698$

Chen, G.-Q. (2009). "A microbial polyhydroxyalkanoates (PHA) based bio- and materials industry," Chemical Society Reviews 38(8), 2434-2446. DOI: $10.1039 / \mathrm{b} 812677 \mathrm{c}$

Chun, K. S., Husseinsyah, S., and Osman, H. (2012). "Mechanical and thermal properties of coconut shell powder filled polylactic acid biocomposites: Effects of the filler content and silane coupling agent," Journal of Polymer Research 19(5). DOI: 10.1007/s 10965-012-9859-8

Costa, A. R. M., Almeida, T. G., Silva, S. M. L., Carvalho, L. H., and Canedo, E. L. (2015). "Chain extension in poly(butylene-adipate-terephthalate). Inline testing in a laboratory internal mixer," Polymer Testing 42, 115-121. DOI: 10.1016/j.polymertesting.2015.01.007

Daud, Z., Mohd Hatta, M. Z., Mohd Kassim, A. S., Awang, H., and Mohd Aripin, A. (2014). "Exploring of agro waste (pineapple leaf, corn stalk, and napier grass) by chemical composition and morphological study," BioResources 9(1), 872-880. DOI: 10.15376/biores.9.1.872-880

Deepa, B., Abraham, E., Cherian, B. M., Bismarck, A., Blaker, J. J., Pothan, L. A., Leao, A. L., de Souza, S. F., and Kottaisamy, M. (2011). "Structure, morphology and thermal characteristics of banana nano fibers obtained by steam explosion," Bioresource Technology 102(2), 1988-1997. DOI: 10.1016/j.biortech.2010.09.030

Deng, Q., and Zhao, Y. (2011). "Physicochemical, nutritional, and antimicrobial properties of wine grape (cv. Merlot) pomace extract-based films," Journal of Food 
Science 76(3), E309-E317. DOI: 10.1111/j.1750-3841.2011.02090.x

Diakosavvas, D. (2017). Improving Energy Efficiency in the Agro-food Chain, Organisation for Economic Co-operation and Development (OECD), Paris, France.

Dong, Y., Ghataura, A., Takagi, H., Haroosh, H. J., Nakagaito, A. N., and Lau, K.-T. (2014). "Polylactic acid (PLA) biocomposites reinforced with coir fibres: Evaluation of mechanical performance and multifunctional properties," Composites Part A:

Applied Science and Manufacturing 63, 76-84. DOI:

10.1016/j.compositesa.2014.04.003

Durowaye, S. I., Lawal, G. I., Akande, M. A., and Durowaye, V. O. (2014). "Mechanical properties of particulate coconut shell and palm fruit polyester composites,"

International Journal of Materials Engineering 4(4), 141-147. DOI:

10.5923/j.ijme.20140404.04

Dwyer, K., Hosseinian, F., and Rod, M. (2014). "The market potential of grape waste alternatives," Journal of Food Research 3(2), 91-106. DOI: 10.5539/jfr.v3n2p91

Ellen MacArthur Foundation (2017). "What is a circular economy?," (https://www.ellenmacarthurfoundation.org/circular-economy/concept), Accessed 5 January 2019.

Essabir, H., Bensalah, M. O., Rodrigue, D., Bouhfid, R., and Qaiss, A. (2016).

"Structural, mechanical and thermal properties of bio-based hybrid composites from waste coir residues: Fibers and shell particles," Mechanics of Materials 93, 134-144. DOI: $10.1016 /$ j.mechmat.2015.10.018

FAO (2019a). "Banana facts and figures," Food and Agriculture Organization of the United Nations (http://www.fao.org/economic/est/estcommodities/bananas/bananafacts/en/\#.XG1X8FxKi70), Accessed 20 February 2019.

FAO (2019b). "Crops," Food and Agriculture Organization of the United Nations, (http://www.fao.org/faostat/en/\#data/QC), Accessed 12 February 2019.

Faruk, O., Bledzki, A. K., Fink, H.-P., and Sain, M. (2012). "Biocomposites reinforced with natural fibers: 2000-2010," Progress in Polymer Science 37(11), 1552-1596. DOI: 10.1016/j.progpolymsci.2012.04.003

Fu, S.-Y., Feng, X.-Q., Lauke, B., and Mai, Y.-W. (2008). "Effects of particle size, particle/matrix interface adhesion and particle loading on mechanical properties of particulate-polymer composites," Composites Part B: Engineering 39(6), 933-961. DOI: 10.1016/j.compositesb.2008.01.002

Fujimaki, T. (1998). "Processability and properties of aliphatic polyesters, 'BIONOLLE', synthesized by polycondensation reaction," Polymer Degradation and Stability 59(13), 209-214. DOI: 10.1016/s0141-3910(97)00220-6

Gaikwad, K. K., Lee, J. Y., and Lee, Y. S. (2016). "Development of polyvinyl alcohol and apple pomace bio-composite film with antioxidant properties for active food packaging application," Journal of Food Science and Technology 53(3), 1608-1619. DOI: $10.1007 / \mathrm{s} 13197-015-2104-9$

Garlotta, D. (2001). "A literature review of poly(lactic acid)," Journal of Polymers and the Environment 9(2), 63-84. DOI: 10.1023/A:1020200822435

Gassara, F., Brar, S. K., Pelletier, F., Verma, M., Godbout, S., and Tyagi, R. D. (2011). "Pomace waste management scenarios in Québec-Impact on greenhouse gas emissions," Journal of Hazardous Materials 192(3), 1178-1185. DOI: 10.1016/j.jhazmat.2011.06.026

Gómez-Brandón, M., Lazcano, C., Lores, M., and Domínguez, J. (2011). “Short-term stabilization of grape marc through earthworms," Journal of Hazardous Materials 
187(1-3), 291-295. DOI: 10.1016/j.jhazmat.2011.01.011

Göpferich, A. (1996). "Mechanisms of polymer degradation and erosion," Biomaterials 17(2), 103-114. DOI: 10.1016/0142-9612(96)85755-3

Gouw, V. P., Jung, J., Simonsen, J., and Zhao, Y. (2017). "Fruit pomace as a source of alternative fibers and cellulose nanofiber as reinforcement agent to create molded pulp packaging boards," Composites Part A: Applied Science and Manufacturing 99, 48-57. DOI: 10.1016/j.compositesa.2017.04.007

Gowman, A. C., Picard, M. C., Rodriguez-Uribe, A., Misra, M., Khalil, H., Thimmanagari, M., and Mohanty, A. K. (2019). "Physicochemical analysis of apple and grape pomaces," BioResources 14(2), 3210-3230. DOI:

10.15376/biores.14.2.3210-3230

Gowman, A., Wang, T., Rodriguez-Uribe, A., Mohanty, A. K., and Misra, M. (2018). "Bio-poly(butylene succinate) and its composites with grape pomace: Mechanical performance and thermal properties," ACS Omega 3(11), 15205-15216. DOI: 10.1021/acsomega.8b01675

Graichen, F. H. M., Grigsby, W. J., Hill, S. J., Raymond, L. G., Sanglard, M., Smith, D. A., Thorlby, G. J., Torr, K. M., and Warnes, J. M. (2017). "Yes, we can make money out of lignin and other bio-based resources," Industrial Crops and Products 106, 7485. DOI: 10.1016/j.indcrop.2016.10.036

Guerrero, M. R. B., Marques da Silva Paula, M., Zaragoza, M. M., Gutiérrez, J. S., Velderrain, V. G., Ortiz, A. L., and Collins-Martínez, V. (2014). "Thermogravimetric study on the pyrolysis kinetics of apple pomace as waste biomass," International Journal of Hydrogen Energy 39(29), 16619-16627. DOI:

10.1016/j.ijhydene.2014.06.012

Gustavsson, J., Cederberg, C., Sonesson, U., van Otterdijk, R., and Meybeck, A. (2011). Global Food Losses and Food Waste - Extent, Causes and Prevention, Food and Agriculture Organization of the United Nations, Rome, Italy.

Hammoui, Y., Molina-Boisseau, S., Duval, A., Djerrada, N., Adjeroud, N., Remini, H., Dahmoune, F., and Madani, K. (2015). "Preparation of plasticized wheat gluten/olive pomace powder biocomposite: Effect of powder content and chemical modifications," Materials \& Design 87, 742-749. DOI: 10.1016/j.matdes.2015.08.080

Hassaini, L., Kaci, M., Touati, N., Pillin, I., Kervoelen, A., and Bruzaud, S. (2017). "Valorization of olive husk flour as a filler for biocomposites based on poly(3hydroxybutyrate-co-3-hydroxyvalerate): Effects of silane treatment," Polymer Testing 59, 430-440. DOI: 10.1016/j.polymertesting.2017.03.004

Hemsri, S., Grieco, K., Asandei, A. D., and Parnas, R. S. (2012). "Wheat gluten composites reinforced with coconut fiber," Composites Part A: Applied Science and Manufacturing 43(7), 1160-1168. DOI: 10.1016/j.compositesa.2012.02.011

Huda, M. S., Drzal, L. T., Mohanty, A. K., and Misra, M. (2008). "Effect of chemical modifications of the pineapple leaf fiber surfaces on the interfacial and mechanical properties of laminated biocomposites," Composite Interfaces 15(2-3), 169-191. DOI: $10.1163 / 156855408783810920$

Isadounene, S., Boukerrou, A., and Hammiche, D. (2017). "Study of biocomposites based of poly(lactic acid) and olive husk flour," International Journal of Chemical and Molecular Engineering 11(4), 356-359.

Isadounene, S., Hammiche, D., Boukerrou, A., Rodrigue, D., and Djidjelli, H. (2018). "Accelerated ageing of alkali treated olive husk flour reinforced polylactic acid (PLA) biocomposites: Physico-mechanical properties," Polymers and Polymer 
Composites 26(3), 223-232. DOI: doi.org/10.1177/096739111802600302

Iwata, T. (2015). "Biodegradable and bio-based polymers: Future prospects of ecofriendly plastics," Angewandte Chemie International Edition 54(11), 3210-3215. DOI: 10.1002/anie.201410770

Jaafar, J., Siregar, J. P., Oumer, A. N., Hamdan, M. H. M., Tezara, C., and Salit, M. S. (2018). "Experimental investigation on performance of short pineapple leaf fiber reinforced tapioca biopolymer composites," BioResources 13(3), 6341-6355. DOI: 10.15376/biores.13.3.6341-6355

Jandas, P. J., Mohanty, S., and Nayak, S. K. (2012). "Renewable resource-based biocomposites of various surface treated banana fiber and poly lactic acid: Characterization and biodegradability," Journal of Polymers and the Environment 20(2), 583-595. DOI: 10.1007/s10924-012-0415-8

Jandas, P. J., Mohanty, S., and Nayak, S. K. (2013a). "Mechanical properties of surfacetreated banana fiber/polylactic acid biocomposites: A comparative study of theoretical and experimental values," Journal of Applied Polymer Science 127(5), 4027-4038. DOI: 10.1002/app.37978

Jandas, P. J., Mohanty, S., and Nayak, S. K. (2013b). "Surface treated banana fiber reinforced poly (lactic acid) nanocomposites for disposable applications," Journal of Cleaner Production 52, 392-401. DOI: 10.1016/j.jclepro.2013.03.033

Jandas, P. J., Mohanty, S., and Nayak, S. K. (2013c). "Thermal properties and cold crystallization kinetics of surface-treated banana fiber (BF)-reinforced poly(lactic acid) (PLA) nanocomposites," Journal of Thermal Analysis and Calorimetry 114(3), 1265-1278. DOI: 10.1007/s10973-013-3102-7

Jandas, P. J., Mohanty, S., Nayak, S. K., and Srivastava, H. (2011). "Effect of surface treatments of banana fiber on mechanical, thermal, and biodegradability properties of PLA/banana fiber biocomposites," Polymer Composites 32(11), 1689-1700. DOI: $10.1002 /$ pc. 21165

Jang, J. Y., Jeong, T. K., Oh, H. J., Youn, J. R., and Song, Y. S. (2012). “Thermal stability and flammability of coconut fiber reinforced poly(lactic acid) composites," Composites Part B: Engineering 43(5), 2434-2438. DOI:

10.1016/j.compositesb.2011.11.003

Jiang, Y., Simonsen, J., and Zhao, Y. (2011). "Compression-molded biocomposite boards from red and white wine grape pomaces," Journal of Applied Polymer Science 119(5), 2834-2846. DOI: 10.1002/app.32961

Joseph, K., Thomas, S., and Pavithran, C. (1996). "Effect of chemical treatment on the tensile properties of short sisal fibre-reinforced polyethylene composites," Polymer 37(23), 5139-5149. DOI: 10.1016/0032-3861(96)00144-9

Kalia, S., Kaith, B. S., and Kaur, I. (2009). "Pretreatments of natural fibers and their application as reinforcing material in polymer composites-A review," Polymer Engineering and Science 49(7), 1253-1272. DOI: 10.1002/pen.21328

Khan, N., le Roes-Hill, M., Welz, P. J., Grandin, K. A., Kudanga, T., van Dyk, J. S., Ohlhoff, C., van Zyl, W. H. (E.), and Pletschke, B. I. (2015). "Fruit waste streams in South Africa and their potential role in developing a bio-economy," South African Journal of Science 111(5-6). DOI: 10.17159/sajs.2015/20140189

Khemakhem, M., Lamnawar, K., Maazouz, A., and Jaziri, M. (2018a). "Effect of coreshell acrylate rubber particles on the thermomechanical and physical properties of biocomposites from polylactic acid and olive solid waste," Polymer Engineering and Science 58(6), 894-902. DOI: 10.1002/pen.24642 
Khemakhem, M., Lamnawar, K., Maazouz, A., and Jaziri, M. (2018b). "Biocomposites based on polylactic acid and olive solid waste fillers: Effect of two compatibilization approaches on the physicochemical, rheological, and mechanical properties," Polymer Composites 39(S1), E152-E163. DOI: 10.1002/pc.24094

Kim, K.-W., Lee, B.-H., Kim, H.-J., Sriroth, K., and Dorgan, J. R. (2012). "Thermal and mechanical properties of cassava and pineapple flours-filled PLA bio-composites," Journal of Thermal Analysis and Calorimetry 108(3), 1131-1139. DOI: 10.1007/s10973-011-1350-y

Kim, H.-S., Yang, H.-S., Kim, H.-J., Lee, B.-J., and Hwang, T.-S. (2005). "Thermal properties of agro-flour-filled biodegradable polymer bio-composites," Journal of Thermal Analysis and Calorimetry 81(2), 299-306. DOI: 10.1007/s10973-005-0782-7

Koutsomitopoulou, A. F., Bénézet, J. C., Bergeret, A., and Papanicolaou, G. C. (2014). "Preparation and characterization of olive pit powder as a filler to PLA-matrix biocomposites," Powder Technology 255, 10-16. DOI: 10.1016/j.powtec.2013.10.047

Kroyer, G. T. (1995). "Impact of food processing on the environment-An overview," LWT - Food Science and Technology 28(6), 547-552. DOI: 10.1016/00236438(95)90000-4

La Mantia, F. P., and Morreale, M. (2011). "Green composites: A brief review," Composites Part A: Applied Science and Manufacturing 42(6), 579-588. DOI: 10.1016/j.compositesa.2011.01.017

Lee, M. C., Koay, S. C., Chan, M. Y., Pang, M. M., Chou, P. M., and Tsai, K. Y. (2018). "Preparation and characterization of durian husk fiber filled polylactic acid biocomposites," MATEC Web of Conferences 152. DOI: $10.1051 /$ matecconf/201815202007

Li, K., Fu, S., Zhan, H., Zhan, Y., and Lucia, L. A. (2010). "Analysis of the chemical composition and morphological structure of banana pseudo-stem," BioResources, 5(2), 576-585.

Li, X., Tabil, L. G., and Panigrahi, S. (2007). "Chemical treatments of natural fiber for use in natural fiber-reinforced composites: A review," Journal of Polymers and the Environment 15(1), 25-33. DOI: 10.1007/s10924-006-0042-3

Lima, E. M. B., Lima, A. M., Minguita, A. P. S., dos Santos, N. R. R., Pereira, I. C. S., Neves, T. T. M., Gonçalves, L. F. d. C., Moreira, A. P. D., Middea, A., Neumann, R., et al. (2019). "Poly(lactic acid) biocomposites with mango waste and organomontmorillonite for packaging," Journal of Applied Polymer Science 136(21). DOI: 10.1002/app.47512

Liu, W., Misra, M., Askeland, P., Drzal, L. T., and Mohanty, A. K. (2005). “'Green' composites from soy based plastic and pineapple leaf fiber: Fabrication and properties evaluation," Polymer 46(8), 2710-2721. DOI: 10.1016/j.polymer.2005.01.027

Liu, W., Wang, Y.-J., and Sun, Z. (2003). "Effects of polyethylene-grafted maleic anhydride (PE-g-MA) on thermal properties, morphology, and tensile properties of low-density polyethylene (LDPE) and corn starch blends," Journal of Applied Polymer Science 88(13), 2904-2911. DOI: 10.1002/app.11965

Luchese, C. L., Garrido, T., Spada, J. C., Tessaro, I. C., and de la Caba, K. (2018). "Development and characterization of cassava starch films incorporated with blueberry pomace," International Journal of Biological Macromolecules 106, 834839. DOI: 10.1016/j.ijbiomac.2017.08.083

Majhi, S. K., Nayak, S. K., Mohanty, S., and Unnikrishnan, L. (2010). "Mechanical and fracture behavior of banana fiber reinforced polylactic acid biocomposites," 
International Journal of Plastics Technology 14(Supplement 1), 57-75. DOI: 10.1007/s12588-010-0010-6

Manshor, M. R., Anuar, H., Nur Aimi, M. N., Ahmad Fitrie, M. I., Wan Nazri, W. B., Sapuan, S. M., El-Shekeil, Y. A., and Wahit, M. U. (2014). "Mechanical, thermal and morphological properties of durian skin fibre reinforced PLA biocomposites," Materials \& Design 59, 279-286. DOI: 10.1016/j.matdes.2014.02.062

McHugh, T. H., and Krochta, J. M. (1994). "Sorbitol- vs glycerol-plasticized whey protein edible films: Integrated oxygen permeability and tensile property evaluation," Journal of Agricultural and Food Chemistry 42(4), 841-845. DOI: 10.1021/jf00040a001

McKeen, L. (2012). "Renewable resource and biodegradable polymers," in: The Effect of Sterilization on Plastics and Elastomers, L. McKeen (ed.), Elsevier, Amsterdam, The Netherlands. DOI: 10.1016/B978-1-4557-2598-4.00012-5

Mekonnen, T., Mussone, P., Khalil, H., and Bressler, D. (2013). "Progress in bio-based plastics and plasticizing modifications," Journal of Materials Chemistry A 1(43), 13379-13398. DOI: 10.1039/c3ta12555f

Merlini, C., Soldi, V., and Barra, G. M. O. (2011). "Influence of fiber surface treatment and length on physico-chemical properties of short random banana fiber-reinforced castor oil polyurethane composites," Polymer Testing 30(8), 833-840. DOI: 10.1016/j.polymertesting.2011.08.008

Mittal, V., Chaudhry, A. U., and Matsko, N. B. (2014). “'True' biocomposites with biopolyesters and date seed powder: Mechanical, thermal, and degradation properties," Journal of Applied Polymer Science 131(19). DOI: 10.1002/app.40816

Mittal, V., Luckachan, G. E., Chernev, B., and Matsko, N. B. (2015). "Bio-polyester-date seed powder composites: Morphology and component migration," Polymer Engineering and Science 55(4), 877-888. DOI: 10.1002/pen.23955

Mohanty, A. K., Misra, M., and Drzal, L. T. (2001). "Surface modifications of natural fibers and performance of the resulting biocomposites: An overview," Composite Interfaces 8(5), 313-343. DOI: 10.1163/156855401753255422

Mohanty, A. K., Misra, M., and Hinrichsen, G. (2000). "Biofibres, biodegradable polymers and biocomposites: An overview," Macromolecular Materials and Engineering 276-277(1), 1-24. DOI: 10.1002/(SICI)14392054(20000301)276:1<1::AID-MAME1>3.0.CO;2-W

Mohanty, A. K., Vivekanandhan, S., Pin, J.-M., and Misra, M. (2018). "Composites from renewable and sustainable resources: Challenges and innovations," Science 362(6414), 536-542. DOI: 10.1126/science.aat9072

Mohanty, A. K., Wibowo, A., Misra, M., and Drzal, L. T. (2004). "Effect of process engineering on the performance of natural fiber reinforced cellulose acetate biocomposites," Composites Part A: Applied Science and Manufacturing 35(3), 363370. DOI: 10.1016/j.compositesa.2003.09.015

Mohanty, A., Misra, M., and Drzal, L. T. (eds.) (2005). Natural Fibers, Biopolymers, and Biocomposites, CRC Press, Boca Raton, FL, USA. DOI: 10.1201/9780203508206

Muensri, P., Kunanopparat, T., Menut, P., and Siriwattanayotin, S. (2011). "Effect of lignin removal on the properties of coconut coir fiber/wheat gluten biocomposite," Composites Part A: Applied Science and Manufacturing 42(2), 173-179. DOI: 10.1016/j.compositesa.2010.11.002

Muthuraj, R., Misra, M., and Mohanty, A. K. (2018). "Biodegradable compatibilized polymer blends for packaging applications: A literature review," Journal of Applied 
Polymer Science 135(24). DOI: 10.1002/app.45726

Nagarajan, V., Mohanty, A. K., and Misra, M. (2016). "Perspective on polylactic acid (PLA) based sustainable materials for durable applications: Focus on toughness and heat resistance," ACS Sustainable Chemistry \& Engineering 4(6), 2899-2916. DOI: 10.1021/acssuschemeng.6b00321

Naghmouchi, I., Mutjé, P., and Boufi, S. (2015). "Olive stones flour as reinforcement in polypropylene composites: A step forward in the valorization of the solid waste from the olive oil industry," Industrial Crops and Products 72, 183-191. DOI: 10.1016/j.indcrop.2014.11.051

Nam, T. H., Ogihara, S., Tung, N. H., and Kobayashi, S. (2011). "Effect of alkali treatment on interfacial and mechanical properties of coir fiber reinforced poly(butylene succinate) biodegradable composites," Composites Part B: Engineering 42(6), 1648-1656. DOI: 10.1016/j.compositesb.2011.04.001

Nazir, M. S., Wahjoedi, B. A., Yussof, A. W., and Abdullah, M. A. (2013). "Eco-friendly extraction and characterization of cellulose from oil palm empty fruit bunches," BioResources 8(2), 2161-2172. DOI: 10.15376/biores.8.2.2161-2172

Negro, V., Ruggeri, B., Fino, D., and Tonini, D. (2017). "Life cycle assessment of orange peel waste management," Resources, Conservation and Recycling 127, 148-158. DOI: 10.1016/j.resconrec.2017.08.014

Nisticò, R., Evon, P., Labonne, L., Vaca-Medina, G., Montoneri, E., Vaca-Garcia, C., and Negre, M. (2017). "Post-harvest tomato plants and urban food wastes for manufacturing plastic films," Journal of Cleaner Production 167. DOI: 10.1016/j.jclepro.2017.08.160

Oliveira, E. I. S., Santos, J. B., Gonçalves, A. P. B., Mattedi, S., and José, N. M. (2016). "Characterization of the rambutan peel fiber (Nephelium lappaceum) as a lignocellulosic material for technological applications," Chemical Engineering Transactions 50, 391-396. DOI: 10.3303/CET1650066

Ooi, Z. X., Ismail, H., Abu Bakar, A., and Aziz, N. A. (2011). "Effects of jackfruit waste flour on properties of poly(vinyl alcohol) film," Journal of Vinyl \& Additive Technology 17(3), 198-208. DOI: 10.1002/vnl.20269

Pagliaro, M., Ciriminna, R., Kimura, H., Rossi, M., and Della Pina, C. (2007). "From glycerol to value-added products," Angewandte Chemie International Edition 46(24), 4434-4440. DOI: 10.1002/anie.200604694

Park, S.-I., Jiang, Y., Simonsen, J., and Zhao, Y. (2009). "Feasibility of creating compression-molded biocomposite boards from berry fruit pomaces," Journal of Applied Polymer Science 115(1), 127-136. DOI: 10.1002/app.30951

Park, S. J., Kim, T. W., Kim, M. K., Lee, S. Y., and Lim, S.-C. (2012). “Advanced bacterial polyhydroxyalkanoates: Towards a versatile and sustainable platform for unnatural tailor-made polyesters," Biotechnology Advances 30(6), 1196-1206. DOI: 10.1016/j.biotechadv.2011.11.007

Penjumras, P., Abdul Rahman, R., Talib, R. A., and Abdan, K. (2016). "Mechanical properties and water absorption behaviour of durian rind cellulose reinforced poly(lactic acid) biocomposites," International Journal on Advanced Science, Engineering and Information Technology 5(5), 343-349. DOI:

10.18517/ijaseit.5.5.574

Philip, S., Keshavarz, T., and Roy, I. (2007). "Polyhydroxyalkanoates: Biodegradable polymers with a range of applications," Journal of Chemical Technology and Biotechnology 82(3), 233-247. DOI: 10.1002/jctb.1667 
Picard, M. C., Rodriguez-Uribe, A., Thimmanagari, M., Misra, M., and Mohanty, A. K. (2019). "Sustainable biocomposites from poly(butylene succinate) and apple pomace: A study on compatibilization performance," Waste and Biomass Valorization. DOI: 10.1007/s12649-019-00591-3

Podgorski, L., and Roux, M. (1999). "Wood modification to improve the durability of coatings," Surface Coatings International 82(12), 590-596. DOI:

10.1007/BF02692672

Podgorski, L., Chevet, B., Onic, L., and Merlin, A. (2000). "Modification of wood wettability by plasma and corona treatments," International Journal of Adhesion and Adhesives 20(2), 103-111. DOI: 10.1016/S0143-7496(99)00043-3

Ramli, S. N. R., Fadzullah, S. H. S. M., and Mustafa, Z. (2016). "The effect of alkaline treatment and fiber length on pineapple leaf fiber reinforced poly lactic acid biocomposites," Jurnal Teknologi 79(4-2), 111-115. DOI: 10.11113/jt.v79.11293

Razak, N. I. A., Ibrahim, N. A., Zainuddin, N., Rayung, M., and Saad, W. Z. (2014). "The influence of chemical surface modification of kenaf fiber using hydrogen peroxide on the mechanical properties of biodegradable kenaf fiber/poly(lactic acid) composites," Molecules 19(3), 2957-2968. DOI: 10.3390/molecules19032957

Reddy, C. S. K., Ghai, R., Rashmi, and Kalia, V. C. (2003). "Polyhydroxyalkanoates: An overview," Bioresource Technology 87(2), 137-146. DOI: 10.1016/S09608524(02)00212-2

Rosa, M. F., Chiou, B.-s., Medeiros, E. S., Wood, D. F., Williams, T. G., Mattoso, L. H. C., Orts, W. J., and Imam, S. H. (2009). "Effect of fiber treatments on tensile and thermal properties of starch/ethylene vinyl alcohol copolymers/coir biocomposites," Bioresource Technology 100(21), 5196-5202. DOI: 10.1016/j.biortech.2009.03.085

Rosentrater, K. A. (2004). "Strategic methodology for advancing food manufacturing waste management paradigms," in: Proceedings Volume 5583, Environmentally Conscious Manufacturing IV, S. M. Gupta (ed.), Philadelphia, PA, USA. DOI: $10.1117 / 12.569989$

Rout, J., Misra, M., Tripathy, S. S., Nayak, S. K., and Mohanty, A. K. (2001). 'Novel eco-friendly biodegradable coir-polyester amide biocomposites: Fabrication and properties evaluation," Polymer Composites 22(6), 770-778. DOI: 10.1002/pc. 10579

Rowell, R. M. (2004). “Acetylation of natural fibers to improve performance," Molecular Crystals and Liquid Crystals 418. DOI: 10.1080/15421400490479244

Ruggiero, A., Valášek, P., and Müller, M. (2016). "Exploitation of waste date seeds of Phoenix dactylifera in form of polymeric particle biocomposite: Investigation on adhesion, cohesion and wear," Composites Part B: Engineering 104, 9-16. DOI: 10.1016/j.compositesb.2016.08.014

Sajna, V. P., Mohanty, S., and Nayak, S. K. (2016). "Effect of poly (lactic acid)-graftglycidyl methacrylate as a compatibilizer on properties of poly (lactic acid)/banana fiber biocomposites," Polymers for Advanced Technologies 27(4), 515-524. DOI: 10.1002/pat.3698

Sajna, V. P., Mohanty, S., and Nayak, S. K. (2017a). "A study on thermal degradation kinetics and flammability properties of poly(lactic acid)/banana fiber/nanoclay hybrid bionanocomposites," Polymer Composites 38(10), 2067-2079. DOI:

10.1002/pc. 23779

Sajna, V. P., Mohanty, S., and Nayak, S. K. (2017b). "Influence of nanoclay and graft copolymer on the thermal and flammability properties of poly(lactic acid)/banana fiber biocomposites," Journal of Vinyl and Additive Technology 23(S1), E81-E91. 
DOI: $10.1002 / \mathrm{vnl} .21556$

Salmah, H., Koay, S. C., and Hakimah, O. (2013). "Surface modification of coconut shell powder filled polylactic acid biocomposites," Journal of Thermoplastic Composite Materials 26(6), 809-819. DOI: 10.1177/0892705711429981

Sánchez Orozco, R., Balderas Hernández, P., Roa Morales, G., Ureña Núñez, F., Orozco Villafuerte, J., Lugo Lugo, V., Flores Ramírez, N., Barrera Díaz, C. E., and Cajero Vázquez, P. (2014). "Characterization of lignocellulosic fruit waste as an alternative feedstock for bioethanol production,” BioResources 9(2), 1873-1885. DOI: 10.15376/biores.9.2.1873-1885

Satapathy, S., and Kothapalli, R. V. S. (2018). "Mechanical, dynamic mechanical and thermal properties of banana fiber/recycled high density polyethylene biocomposites filled with flyash cenospheres," Journal of Polymers and the Environment 26(1), 200213. DOI: 10.1007/s10924-017-0938-0

Sgriccia, N., Hawley, M. C., and Misra, M. (2008). "Characterization of natural fiber surfaces and natural fiber composites," Composites Part A: Applied Science and Manufacturing,39(10), 1632-1637. DOI: 10.1016/j.compositesa.2008.07.007

Shalini, R., and Gupta, D. K. (2010). "Utilization of pomace from apple processing industries: A review," Journal of Food Science and Technology 47(4), 365-371. DOI: 10.1007/s13197-010-0061-x

Shaw, N. B., Monahan, F. J., O’Riordan, E. D., and O’Sullivan, M. (2002). "Physical properties of WPI films plasticized with glycerol, xylitol, or sorbitol," Journal of Food Science 67(1), 164-167. DOI: 10.1111/j.1365-2621.2002.tb11377.x

Shih, Y.-F., Chang, W.-C., Liu, W.-C., Lee, C.-C., Kuan, C.-S., and Yu, Y.-H. (2014). "Pineapple leaf/recycled disposable chopstick hybrid fiber-reinforced biodegradable composites," Journal of the Taiwan Institute of Chemical Engineers 45(4), 20392046. DOI: 10.1016/j.jtice.2014.02.015

Siakeng, R., Jawaid, M., Ariffin, H., and Sapuan, S. M. (2019). "Mechanical, dynamic, and thermomechanical properties of coir/pineapple leaf fiber reinforced polylactic acid hybrid biocomposites," Polymer Composites 40(5), 2000-2011. DOI: 10.1002/pc. 24978

Spiridon, I., Nita, R. N. D., Kozlowski, M., Nechita, A., and Ursu, R. G. (2016). "Influence of accelerated weathering on the performance of polylactic acid based materials," Cellulose Chemistry and Technology 50(5-6), 629-635.

Spiridon, I., Ursu, R. G., and Spiridon, I. A. C. (2015). "New polylactic acid composites for packaging applications: Mechanical properties, thermal behavior, and antimicrobial activity," International Journal of Polymer Analysis and Characterization 20(8), 681-692. DOI: 10.1080/1023666X.2015.1081131

Suardana, N. P. G., Lokantara, I. P., and Lim, J. K. (2011). "Influence of water absorption on mechanical properties of coconut coir fiber/poly-lactic acid biocomposites," Materials Physics and Mechanics 12(2), 113-125.

Sudiyani, Y., Styarini, D., Triwahyuni, E., Sudiyarmanto, Sembiring, K. C., Aristiawan, Y., Abimanyu, H., and Han, M. H. (2013). "Utilization of biomass waste empty fruit bunch fiber of palm oil for bioethanol production using pilot-scale unit," Energy Procedia 32, 31-38. DOI: 10.1016/j.egypro.2013.05.005

Tjong, S. C., and Bao, S. P. (2005). "Crystallization regime characteristics of exfoliated polyethylene/vermiculite nanocomposites," Journal of Polymer Science Part B: Polymer Physics 43(3), 253-263. DOI: 10.1002/polb.20324

Tserki, V., Matzinos, P., and Panayiotou, C. (2006). "Novel biodegradable composites 
based on treated lignocellulosic waste flour as filler. Part II. Development of biodegradable composites using treated and compatibilized waste flour," Composites Part A: Applied Science and Manufacturing 37(9), 1231-1238. DOI: 10.1016/j.compositesa.2005.09.004

Tserki, V., Matzinos, P., Kokkou, S., and Panayiotou, C. (2005). "Novel biodegradable composites based on treated lignocellulosic waste flour as filler. Part I. Surface chemical modification and characterization of waste flour," Composites Part A: Applied Science and Manufacturing 36(7), 965-974. DOI: 10.1016/j.compositesa.2004.11.010

USDA (2018). Fresh Deciduous Fruit: World Markets and Trade (Apples, Grapes, \& Pears), United States Department of Agriculture, Foreign Agricultural Service, Washington, DC, USA.

Vendruscolo, F., Albuquerque, P. M., Streit, F., Esposito, E., and Ninow, J. L. (2008). "Apple pomace: A versatile substrate for biotechnological applications," Critical Reviews in Biotechnology 28(1), 1-12. DOI: 10.1080/07388550801913840

Wataya, C. H., Lima, R. A., Oliveira, R. R., and Moura, E. A. B. (2015). "Mechanical, morphological and thermal properties of açaí fibers reinforced biodegradable polymer composites," in: Characterization of Minerals, Metals, and Materials 2015, J. S. Carpenter, C. Bai, J. P. Escobedo, J.-Y. Hwang, S. Ikhmayies, B. Li, J. Li, S. N. Monteiro, Z. Peng, and M. Zhang (eds.), Springer, Cham, Switzerland. 265-272. DOI: 10.1007/978-3-319-48191-3_33

Yang, H.-S., Wolcott, M. P., Kim, H.-S., and Kim, H.-J. (2005). "Thermal properties of lignocellulosic filler-thermoplastic polymer bio-composites," Journal of Thermal Analysis and Calorimetry 82(1), 157-160. DOI: 10.1007/s10973-005-0857-5

Yang, H. S., Wolcott, M. P., Kim, H. J. H. S., and Kim, H. J. H. S. (2005). "Thermal properties of agro-flour-filled biodegradable polymer bio-composites," Journal of Thermal Analysis and Calorimetry 82(2), 157-160. DOI: 10.1007/s10973-005-0782-7

Zamudio-Flores, P. B., Torres, A. V., Salgado-Delgado, R., and Bello-Pérez, L. A. (2010). "Influence of the oxidation and acetylation of banana starch on the mechanical and water barrier properties of modified starch and modified starch/chitosan blend films," Journal of Applied Polymer Science 115(2), 991-998. DOI: 10.1002/app.31047

Zhong, O. X., Ismail, H., Aziz, N. A. A., and Bakar, A. A. (2011). "Preparation and properties of biodegradable polymer film based on polyvinyl alcohol and tropical fruit waste flour," Polymer-Plastics Technology and Engineering 50(7), 705-711. DOI: 10.1080/03602559.2010.551391

Zink, T., and Geyer, R. (2017). "Circular economy rebound," Journal of Industrial Ecology, 21(3), 593-602. DOI: 10.1111/jiec.12545

Article submitted: May 16, 2019; Peer review completed: August 25, 2019; Revised Version received: September 14, 2019; Accepted: September 15, 2019; Published: October 7, 2019.

DOI: 10.15376/biores.14.4.Gowman 